\title{
Source Water Identification and Chemical Typing for Nitrogen at the Kissimmee River, Pool C, Florida--Preliminary Assessment
}

By G. G. Phelps

U.S. GEOLOGICAL SURVEY

Open File Report 02-48

Prepared in cooperation with the

South Florida Water Management District

Contract No. 10712

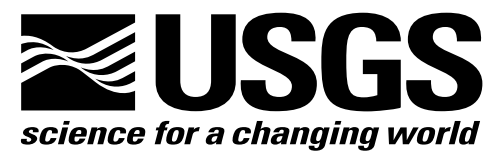

2002 


\title{
U.S. DEPARTMENT OF THE INTERIOR GALE A. NORTON, Secretary
}

\author{
U.S. GEOLOGICAL SURVEY \\ Charles G. Groat, Director
}

The use of firm, trade, and brand names in this report is for identification purposes only and does not constitute endorsement by the U.S. Geological Survey.

For additional information

write to:

District Chief

U.S. Geological Survey, WRD

Suite 3015

227 North Bronough Street

Tallahassee, FL 32301
Copies of this report can be purchased from:

U.S. Geological Survey

Branch of Information Services

Box 25286

Denver, CO 80225-0286

888-ASK-USGS

Additional information about water resources in Florida is available on the World Wide Web at http://fl.water.usgs.gov 


\section{Source Water Identification and Chemical Typing for Nitrogen at the Kissimmee River, Pool C, Florida--Preliminary Assessment}

By G.G. Phelps

U.S. GEOLOGICAL SURVEY

Open File Report 02-48

Prepared in cooperation with the

South Florida Water Management District

Contract No. 10712

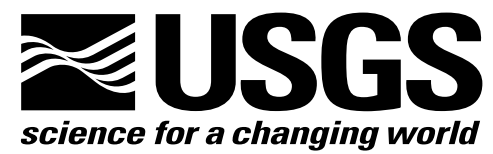

2002 


\title{
U.S. DEPARTMENT OF THE INTERIOR GALE A. NORTON, Secretary
}

\author{
U.S. GEOLOGICAL SURVEY \\ Charles G. Groat, Director
}

The use of firm, trade, and brand names in this report is for identification purposes only and does not constitute endorsement by the U.S. Geological Survey.

For additional information

write to:

District Chief

U.S. Geological Survey, WRD

Suite 3015

227 North Bronough Street

Tallahassee, FL 32301
Copies of this report can be purchased from:

U.S. Geological Survey

Branch of Information Services

Box 25286

Denver, CO 80225-0286

888-ASK-USGS

Additional information about water resources in Florida is available on the World Wide Web at http://fl.water.usgs.gov 


\section{CONTENTS}

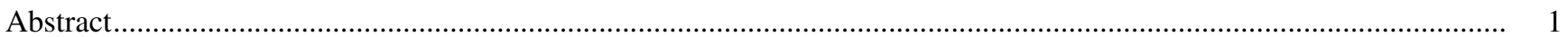

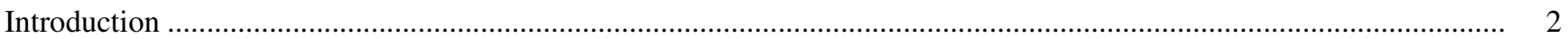

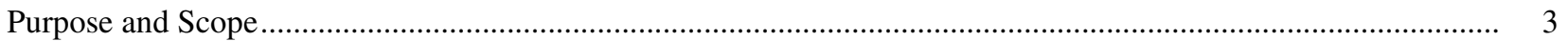

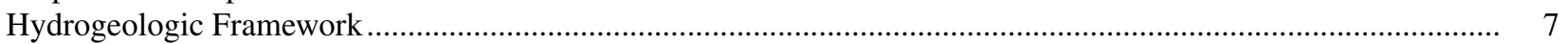

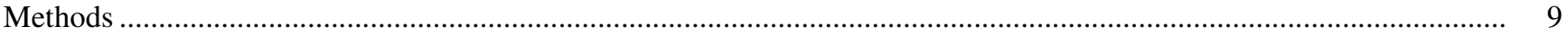

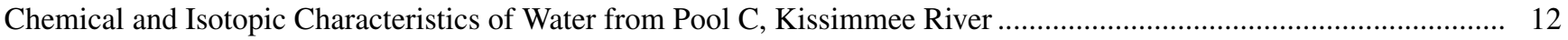

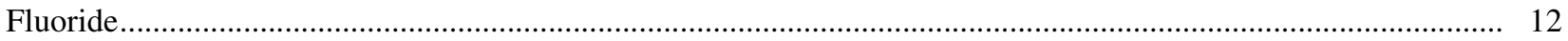

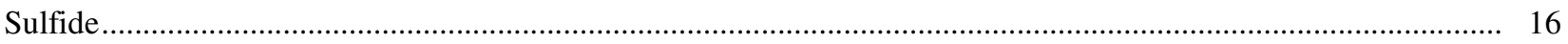

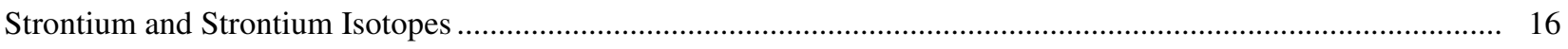

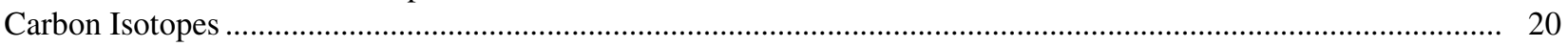

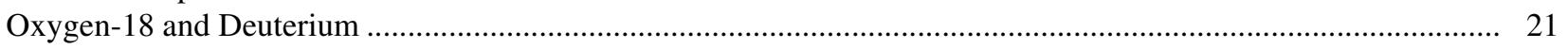

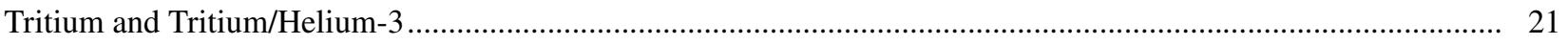

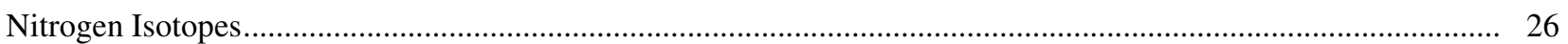

Summary and Comparison of Chemical and Isotopic Data from Sites C and D.................................................... 30

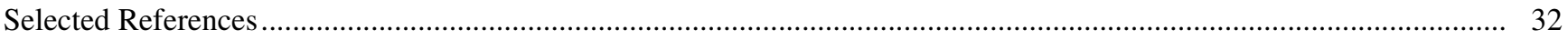

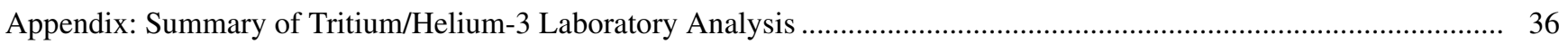

\section{FIGURES}

1. Map showing site location

2. Section showing generalized well layout and construction details for Site C, east bank of C-38 (Pool C) .............. 5

3. Section showing generalized well layout and construction details for Site D, west bank of river channel.............. 6

4. Description of the hydrogeologic and geologic units in Okeechobee County, Florida ....................................... 8

5. Graph showing fluoride concentration as a function of depth and box plots of fluoride concentration data............ 14

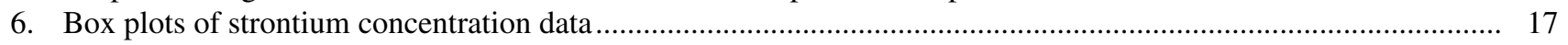

7. Graph showing relation between ratio of strontium- 87 to strontium- 86 and strontium concentration ..................... 19

8. Section showing distribution of tritium and oxygen, hydrogen, and nitrogen isotope data for Site C................... 22

9. Section showing distribution of tritium and oxygen, hydrogen, and nitrogen isotope data for Site D................... 23

10. Graph showing relation between delta deuterium and delta oxygen-18 ...................................................... 24

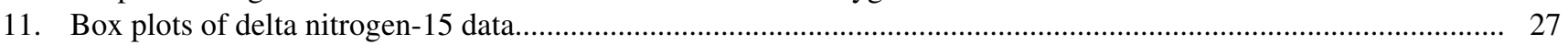

12. Graph showing relation between sampling depth and delta nitrogen-15 values............................................. 28

\section{TABLES}

1. Chemical and isotopic data for Kissimmee River, Pool C, Sites C and D, September-October 1999 ................... 13

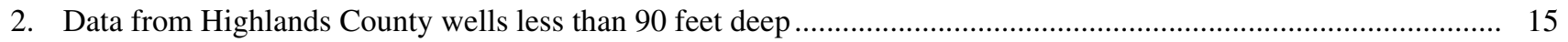

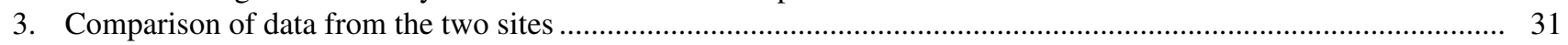




\section{Source Water Identification and Chemical Typing for Nitrogen at the Kissimmee River, Pool C, Florida--Preliminary Assessment}

by G.G. Phelps

\section{ABSTRACT}

As part of the South Florida Water Management District's Ground Water-Surface Water Interactions Study, a project was undertaken to identify the ages and sources of water in the area of Pool C, Kissimmee River, Florida. Twenty-two water samples were collected along two transects: at a remnant river oxbow (Site D) and in the dredged part of the channel (Site C). The samples were analyzed for concentrations of fluoride and strontium, and for isotopes of oxygen, hydrogen, and nitrogen. Selected samples were analyzed for one or more additional isotopes (carbon-14, the ratio of strontium-87 to strontium-86, tritium, and tritium-helium-3). Delta nitrogen-15 values for nitrate at Site C can be explained by soil nitrogen and fertilizer sources; at Site D soil nitrogen accounts for most values, although animal wastes may explain higher values. Some of the isotopic data seem to be contradictory: carbon-14 data apparently indicate that shallow ground water is younger at Site D than at Site C, whereas strontium-87/86 ratios lead to the opposite conclusion. More detailed analysis of major ions and nutrients for all sampling points, along with flow measurements, could allow more definitive interpretation of isotope data and provide additional insight into mixing of ground water and surface water at the sites. 


\section{INTRODUCTION}

When the channelization of the Kissimmee River, Florida, was completed in 1971, a 103-mile segment of the meandering river had been converted into a 56-mile straight channel. This 30 -foot-deep canal (C-38) was partitioned by control structures into five hydrologic pools (Pools A through E, from north to south). The Kissimmee River Restoration Project, a cooperative effort by the South Florida Water Management District (SFWMD) and the U.S. Army Corps of Engineers (USACE), is designed to re-establish a natural river ecosystem. Parts of the C-38 canal will be backfilled, inundating 27,000 acres of drained wetlands and restoring flow to 43 miles of river channel.

An understanding of ground-water/surface-water interactions in both the canal and the natural part of the river flow system is important for understanding water chemistry processes before and after restoration. For this reason, the SFWMD began a Groundwater-Surface Water Interactions Study, in part to investigate seepage of ground water into the Kissimmee River in both the canal and remnant river channels of the original flow system. The deep, box-cut shape of the canal allows relatively large inflows

of ground water, especially at the upstream ends of the pools, where large head differences can develop between the ground-water levels and canal stage (Belanger and others, 1999). The canal excavation removed sediment from a low-permeability layer and may have increased the connection between surface water and the underlying semi-confined zones of the surficial aquifer system. 
A previous study (Belanger and others, 1994) has shown that ground-water inputs to C-38 can adversely affect the dissolved oxygen concentrations in the canal. Another constituent of concern is nitrate nitrogen $\left(\mathrm{NO}_{3}-\mathrm{N}\right)$. Ground water can be a significant source of nitrate to the surface water. The SFWMD requested the U.S. Geological Survey (USGS) to sample ground water and surface water for environmental isotopes and other chemical constituents to better understand the ground-water/surfacewater interactions at two sites in pool C (fig. 1). Site $\mathrm{C}$ is located along the channelized part of the river system and Site D is in a remnant channel area. At each site, a series of monitor wells, piezometers, and seepage meters was installed by the SFWMD to measure heads and collect water samples (figs. 2 and 3). A deep well tapping the Floridan aquifer system (FAS), well OKF-42, also was sampled (fig. 1) because there has been speculation that upward leakage of water from the FAS could be affecting water quality in the surficial aquifer system (SAS). This possibility is considered unlikely because the combined thickness of the SAS and the intermediate confining unit in the area is about $350 \mathrm{ft}$ (Bradner, 1994, figs. 9 and 11). Total depth of the FAS well is $1,150 \mathrm{ft}$, but the casing depth is unknown.

\section{Purpose and Scope}

The purpose of this report is to summarize the analysis of 22 water samples collected at two transects (Sites C and D) in Pool C of the Kissimmee River. All samples were analyzed for concentrations of fluoride and strontium and for isotopes of oxygen, hydrogen, and nitrogen. Selected samples were analyzed for concentrations of sulfide and for one or more additional environmental isotopes (carbon-14, the ratio of strontium-87 to strontium-86, tritium, and tritium-helium-3) to provide information about the possible sources and ages of waters at the two sites. Selection of isotope analyses was made to provide the greatest amount of information possible for the limited amount of funding and time available. 


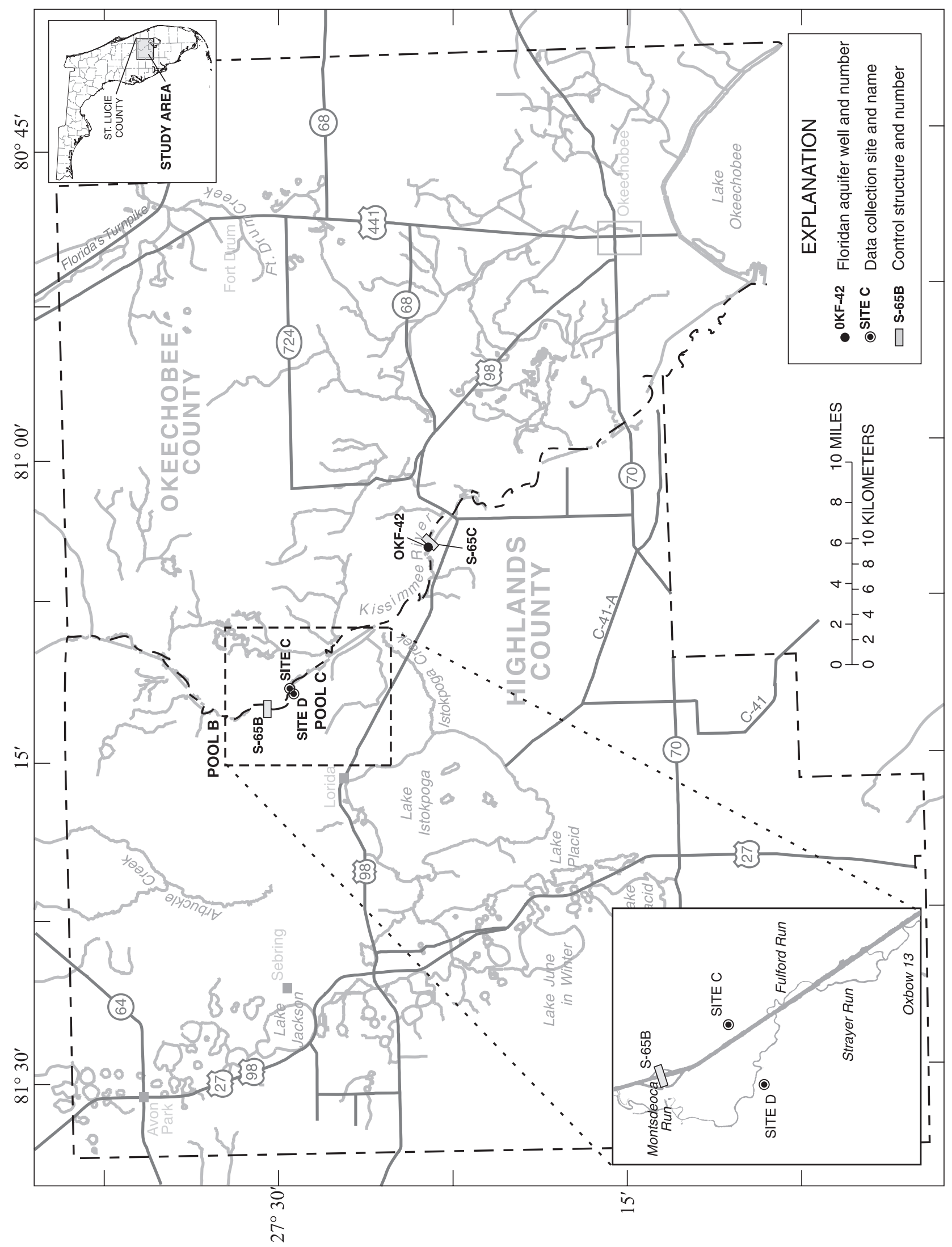

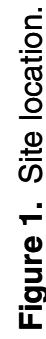




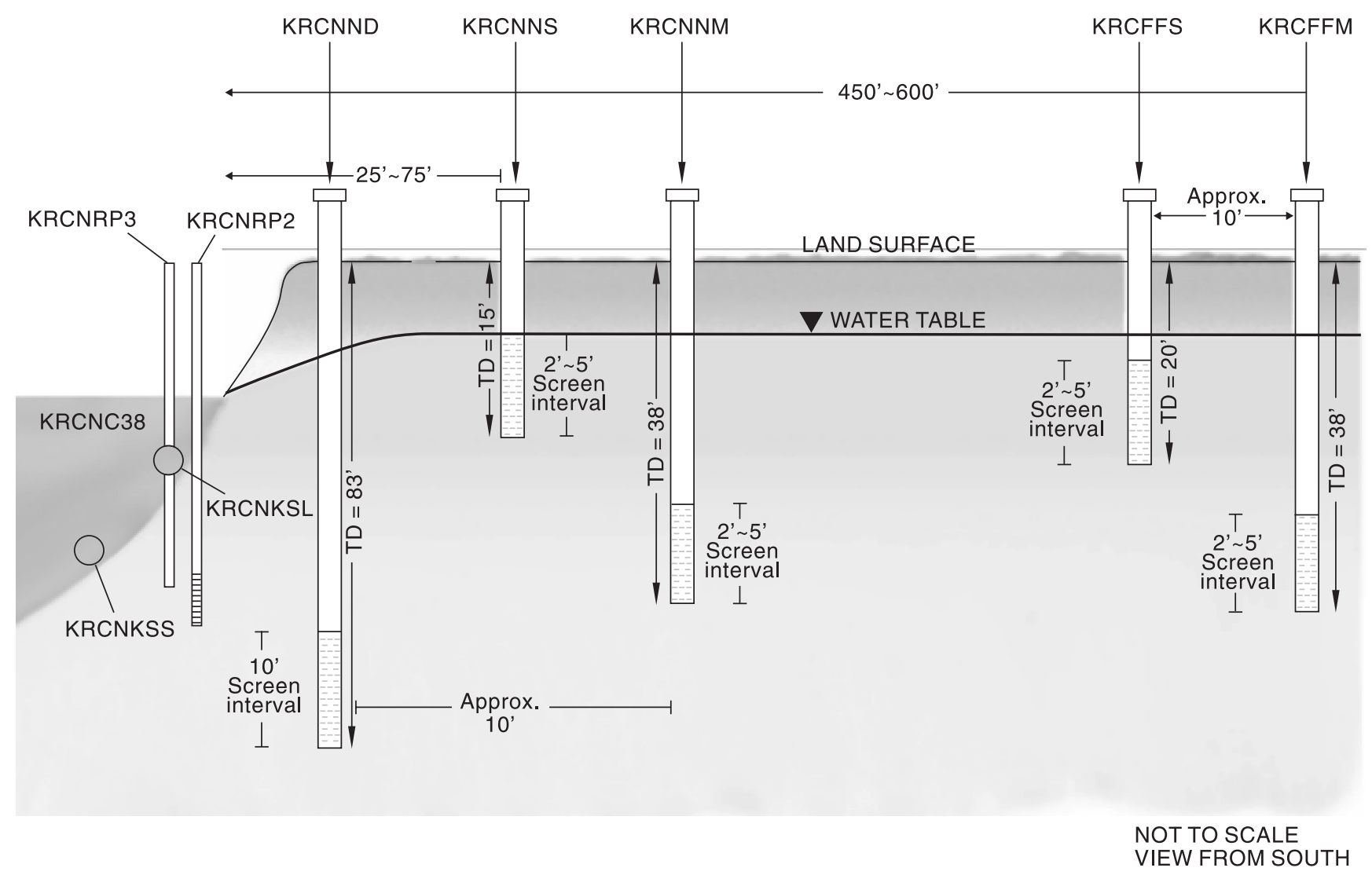

Figure 2. Generalized well layout and construction details for Site C, east bank of C-38 (Pool C). 


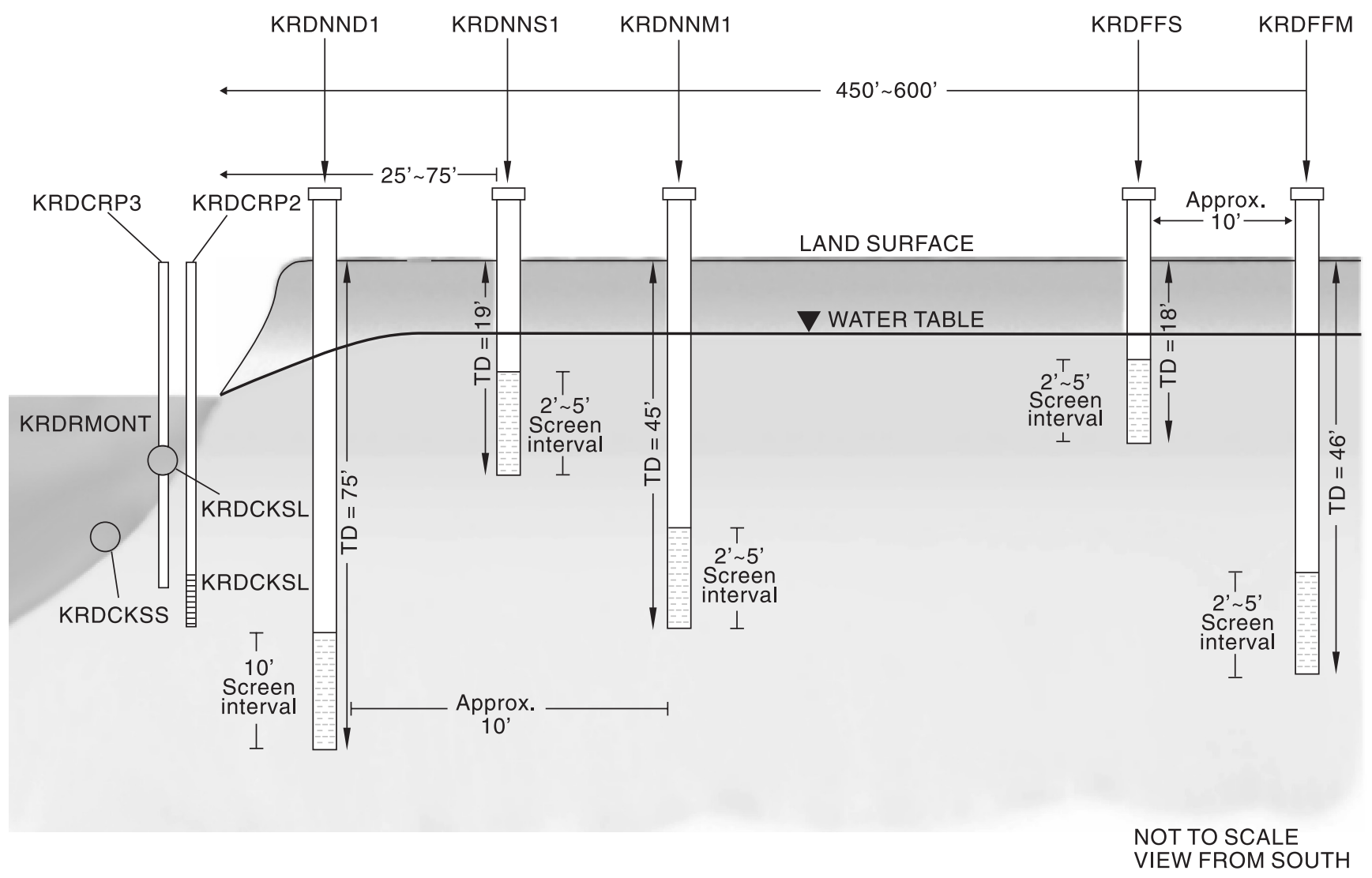

Figure 3. Generalized well layout and construction details for Site D, west bank of river channel. 


\section{Hydrogeologic Framework}

The hydrogeology of south-central Florida has been described by Bishop (1956) and Bradner (1994). In the study area, the surficial sediments consist of undifferentiated sand, clay, silt, and shell deposits of Pleistocene and Holocene age (fig. 4). The sands and shells are interlayered with thin layers of clay, silt, and fine sand. In Okeechobee County, some of the shell layers are as much as 50 feet (ft) thick (Bradner, 1994). Underlying these surficial sediments are deposits of Late Miocene to Pliocene age. These deposits generally consist of clayey sand and silt with lenses of medium to course sand and shell. In some parts of Okeechobee County, these deposits also contain loosely consolidated limestone (Bradner, 1994). The Late Miocene-to Holocene-age sediments generally make up the SAS, although the lower part of the Late Miocene-to-Pliocene-age sediments may be of low permeability and act as a confining unit, rather than an aquifer. In western Okeechobee County, the SAS is between 150-200 $\mathrm{ft}$ thick (Bradner, 1994).

Beneath the Late Miocene-to-Pliocene-age sediments is the Miocene Hawthorn Group, which consists of silty to sandy clay, marl, thin shell beds, and some limestone. Sediments of the Hawthorn Group are phosphatic and can include phosphorite pebbles. Although the Hawthorn Group contains sand and shell, the permeability of the deposits is low. The Hawthorn Group generally acts as a confining unit and is called the intermediate confining unit.

The intermediate confining unit is underlain by thick units of limestone. In some areas of southcentral Florida, the Oligocene-age Suwannee Limestone is present, but in other areas it has been removed by erosion. Underlying the Suwannee Limestone is the Ocala Limestone of Eocene age. The Ocala Limestone is thick and permeable and is the upper unit of the artesian FAS. In western Okeechobee County, the top of the FAS is about $350 \mathrm{ft}$ below land surface (Bradner, 1994). Thus, the thickness of the intermediate confining unit separating the SAS and the FAS in the study area is estimated to be about $150 \mathrm{ft}$. 


\begin{tabular}{|c|c|c|c|c|c|}
\hline SYSTEM & SERIES & $\begin{array}{l}\text { FORMATION } \\
\text { NAME }\end{array}$ & $\begin{array}{l}\text { THICKNESS } \\
\text { (in feet) }\end{array}$ & DESCRIPTION & $\begin{array}{l}\text { HYDROGELOGIC } \\
\text { UNIT }\end{array}$ \\
\hline Quaternary & $\begin{array}{l}\text { Holocene } \\
\text { and } \\
\text { Pleistocene }\end{array}$ & \multirow{2}{*}{$\begin{array}{l}\text { Undifferentiated } \\
\text { deposits }\end{array}$} & $100-250$ & $\begin{array}{l}\text { Variable mixture of sand, shell, } \\
\text { silt, clay, coquina, and organic } \\
\text { material }\end{array}$ & $\begin{array}{l}\text { Surficial aquifer } \\
\text { system }\end{array}$ \\
\hline \multirow{4}{*}{ Tertiary } & Pliocene & & \multirow[b]{2}{*}{$200-400$} & \multirow[b]{2}{*}{$\begin{array}{l}\text { Silty to sandy clay, thin shell } \\
\text { beds, and basal limestone beds } \\
\text { of variable thickness; phosphatic }\end{array}$} & \\
\hline & Miocene & $\begin{array}{l}\text { Hawthorn } \\
\text { Group }\end{array}$ & & & $\begin{array}{l}\text { Intermediate confining } \\
\text { unit }\end{array}$ \\
\hline & Oligocene & $\begin{array}{l}\text { Suwanee } \\
\text { Limestone }\end{array}$ & $0-10$ & Limestone, phosphatic & \multirow{2}{*}{$\begin{array}{l}\text { Upper Floridan } \\
\text { aquifer }\end{array}$} \\
\hline & Eocene & $\begin{array}{l}\text { Ocala } \\
\text { Limestone }\end{array}$ & $100-300$ & $\begin{array}{l}\text { Limestone, dolomitic near base } \\
\text { in places }\end{array}$ & \\
\hline
\end{tabular}

Figure 4. Description of the hydrogeologic and geologic units in Okeechobee County, Florida (modified from Bradner, 1994). 
The study site is in an area of artesian flow of the FAS (the potentiometric surface is above land surface) (Bradner, 1994). The water level in FAS well OKF-42 was about $46 \mathrm{ft}$ above sea level in May 1998 (Adamski, 1998) and $47 \mathrm{ft}$ above sea level in September 1998 (Bradner, 1999). Water levels in the SAS in an 83-ft-deep well at Site C were about $40 \mathrm{ft}$ above sea level in May 1998 and $39.5 \mathrm{ft}$ in September 1998 (Belanger and others, 1999). In a 75-ft-deep SAS well at Site D, the water levels were about $40.5 \mathrm{ft}$ above sea level in May 1998 and $37.5 \mathrm{ft}$ above sea level in September 1998 (Belanger and others, 1999). Thus, based on the head relation between the two aquifers, upward leakage from the FAS to the SAS is possible, although the thickness of the intermediate confining unit would limit the rate at which upward leakage could take place.

\section{METHODS}

Twenty-two water samples were collected in September-October 1999 using standard USGS protocols (Wood, 1976). Sampling originally was scheduled for July-September 1999, but weather delayed the completion until October 1999. Water samples for fluoride and strontium analysis were filtered using 0.45-micrometer capsule filters. Samples for strontium concentration and ratio of strontium-87 to strontium- $86\left({ }^{87} \mathrm{Sr} /{ }^{86} \mathrm{Sr}\right)$ analysis were collected in acid-washed bottles and acidified in the field with 70 percent nitric acid. Samples for sulfide determination were treated in the field with sodium hydroxide to increase $\mathrm{pH}$, followed by the addition of zinc acetate to precipitate zinc sulfide. Concentrations of fluoride, strontium, and sulfide were analyzed at the USGS laboratory in Ocala, Fla. 
Ratios of ${ }^{87} \mathrm{Sr} /{ }^{86} \mathrm{Sr}$ were determined at the USGS Research Laboratory, Menlo Park, Calif., on a Finnigan MAT 261 solid source mass spectrometer. Strontium isotopes were analyzed by the positive ion thermal mass spectrometry technique (T.D. Bullen, USGS, written commun., 2000). For each analysis, sufficient fluid sample containing approximately 1 microgram of strontium was loaded onto a precleaned cation exchange column, and strontium was separated from other cations and the anions using $2 \mathrm{~N}$ hydrochloric acid as the eluent. The strontium fraction was evaporated to dryness with 40 microliters of $0.5 \mathrm{~N}$ phosphoric acid and converted to a nitrate. The sample was then loaded onto a tantalum ribbon filament and placed in the mass spectrometer. Samples were analyzed for isotopic composition using a double collector dynamic data acquisition approach. Measured ${ }^{87} \mathrm{Sr} /{ }^{86} \mathrm{Sr}$ ratios were corrected for all stable isotope fractionation by simultaneously measuring ${ }^{88} \mathrm{Sr} /{ }^{86} \mathrm{Sr}$, correcting this ratio to a value of 8.37521 , and then correcting the ${ }^{87} \mathrm{Sr} /{ }^{86} \mathrm{Sr}$ ratio using an exponential mass-dependent fractionation relation. NIST 987, a widely used standard reference material, routinely gives a value of 0.71024 on this instrument. Reported ${ }^{87} \mathrm{Sr} /{ }^{86} \mathrm{Sr}$ ratios are precise to 0.00002 at the 95 percent confidence level.

Unfiltered samples were collected in glass bottles secured with polyseal caps for deuterium $(\delta \mathrm{D})$ and oxygen-18 $\left(\delta^{18} \mathrm{O}\right)$ analysis of the water and determinations of carbon-14 $\left({ }^{14} \mathrm{C}\right)$ and concentration ratios of carbon-13 to carbon-12 isotopes $\left(\delta^{13} \mathrm{C}\right)$ for dissolved inorganic carbon. For most isotope determinations, standard $\delta$ (delta) notation (Gonfiantini, 1981) is used in units of parts per thousand (per mil), and is expressed by the equation:

$$
\delta_{\text {sample }}=\left[\frac{R_{\text {sample }}}{R_{\text {standard }}}-1\right] \times 1,000,
$$

where $\mathrm{R}$ is the ratio of heavy to light isotope of both sample and standard. 
Concentration ratios of deuterium to hydrogen $(\delta \mathrm{D})$ and oxygen-18 to oxygen-16 $\left(\delta^{18} \mathrm{O}\right)$ were determined by the USGS Isotope Fractionation Laboratory in Reston, Va., using techniques described by Coplen (1988 and 1994). Analytical determinations of ${ }^{14} \mathrm{C}$ and $\delta^{13} \mathrm{C}$ were made by USGS contract laboratories using accelerator mass spectrometry (AMS). Oxygen and hydrogen isotopic results are reported in per mil relative to Vienna Standard Mean Ocean Water (VSMOW), and are normalized on scales such that the oxygen and hydrogen isotopic values of Standard Light Antarctic Precipitation (SLAP) are -55.5 per mil and -428 per mil, respectively. Carbon isotopic results are reported in per mil relative to Vienna PeeDee Belemnite (VPDB). The uncertainties of carbon, oxygen, and hydrogen isotopic results are \pm 0.2 per mil.

Filtered samples were collected for nitrogen isotope determination. The samples were chilled, protected from light, and shipped within 3 days to a USGS contract laboratory. At the laboratory, each sample was distilled with sodium hydroxide and Dvarda's alloys to reduce the nitrate to ammonium. This step was followed by sodium hypobromite oxidation on the vacuum line to produce nitrogen. The nitrogen was purified by passing through a copper-copper oxide furnace and then analyzed by a mass spectrometer to determine the ratio of nitrogen-15 to nitrogen-14 $\left(\delta^{15} \mathrm{~N}\right)$.

Tritium and tritium-helium- $3\left({ }^{3} \mathrm{H} /{ }^{3} \mathrm{He}\right)$ determinations were made by mass spectrometry using the ${ }^{3} \mathrm{He}$ ingrowth method at the Noble Gas Laboratory at the LaMont-Doherty Earth Observatory of Columbia University, N.Y. Raw water samples for analysis of tritium concentration were collected in duplicate in amber glass bottles. Samples for measurement of ${ }^{3} \mathrm{He}$ ingrowth were collected in duplicate in pinched-off copper tubes (L.N. Plummer, USGS, written commun., 1997). Methods for the determination of ${ }^{3} \mathrm{H} /{ }^{3} \mathrm{He}$ ratios have been described by Schlosser (1992). Precision for the measurements is plus or minus 4 percent (or 0.01 Tritium Units) for tritium determinations and plus or minus 0.4 to 2 percent for the ratio ${ }^{3} \mathrm{He} /{ }^{4} \mathrm{He}$. 


\section{CHEMICAL AND ISOTOPIC CHARACTERISTICS OF WATER FROM POOL C, KISSIMMEE RIVER}

A tabulation of results is given in table 1. Constituents analyzed included concentrations of fluoride, strontium, sulfide, and tritium, and determinations of the ratio of ${ }^{87} \mathrm{Sr} /{ }^{86} \mathrm{Sr}, \delta^{13} \mathrm{C}$, percent modern carbon $\left({ }^{14} \mathrm{C}\right), \delta \mathrm{D}, \delta^{18} \mathrm{O}$, and $\delta^{15} \mathrm{~N}$. The following sections present the analytical results for the aforementioned constituents, along with a brief interpretation of these results in relation to interactions between ground water and surface water.

\section{Fluoride}

Concentrations of dissolved fluoride were determined for all samples. The values ranged from less than the detection limit of 0.1 milligrams per liter $(\mathrm{mg} / \mathrm{L})$ for surface water and shallow ground water to $0.52 \mathrm{mg} / \mathrm{L}$ for the sample from well OKF-42, which taps the Floridan aquifer system. The mineral apatite, which contains fluoride and is found in phosphate deposits, can be a source of fluoride in ground water. The median value for samples from Site C (about $0.48 \mathrm{mg} / \mathrm{L}$ ) was higher than the median for samples from Site D (about $0.2 \mathrm{mg} / \mathrm{L}$ ) (fig. 5). Data for 15 wells in Highlands County tapping the SAS with depths of $90 \mathrm{ft}$ or less are shown in table 2 (Bishop, 1956). The median fluoride concentration for those samples is about $0.2 \mathrm{mg} / \mathrm{L}$, which is similar to the value for the samples from Site D. Bishop (1956) also reported that fluoride concentrations for wells tapping the FAS in Highlands County ranged from 0-0.3 mg/L, and for wells tapping the SAS, the range was $0-0.8 \mathrm{mg} / \mathrm{L}$. Given the overlap in ranges, fluoride concentrations cannot be used to differentiate between the influence of FAS or SAS ground water. The higher fluoride concentrations at Site $\mathrm{C}$ for wells of all depths probably indicates a difference in local mineralogy. At Site C, no fluoride was detected in either the seepage meter sample or the surfacewater sample; this may indicate that surface water is recharging the ground water, rather than the opposite. The same may be true at Site D, where both seepage meter samples and the surface-water sample had no detectable fluoride. 


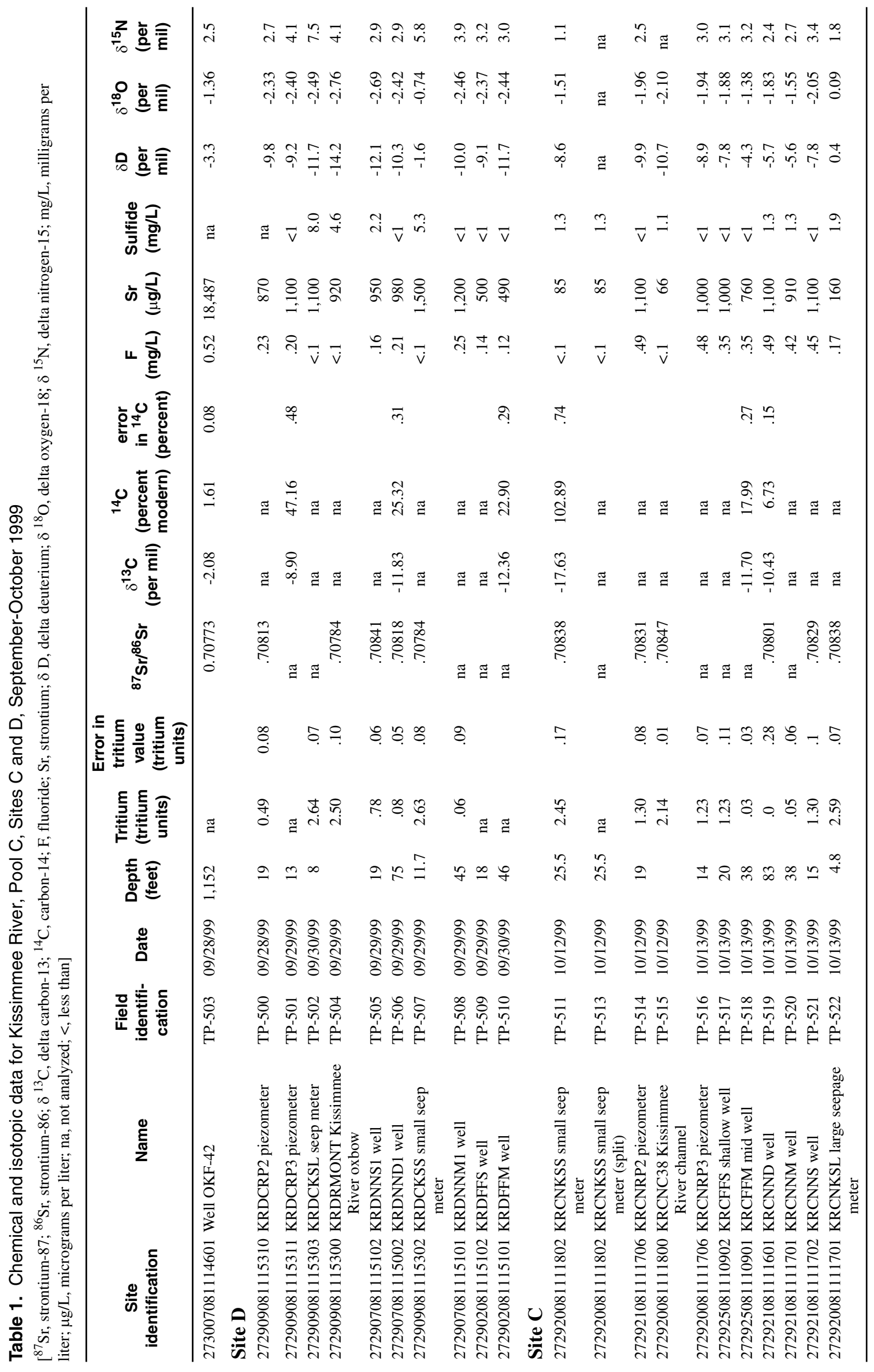



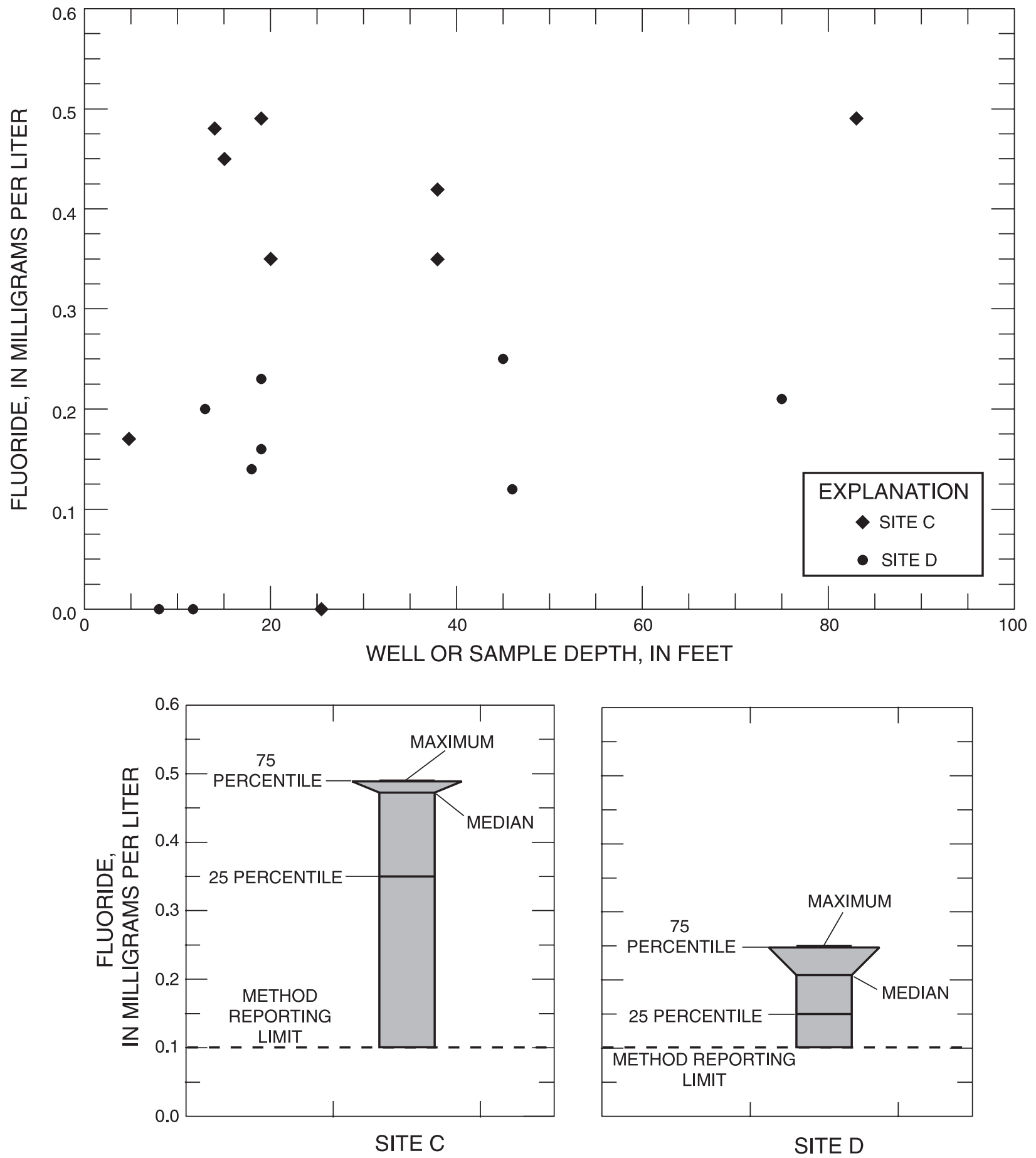

Figure 5. Fluoride concentration as a function of depth and box plots of fluoride concentration data. 
Table 2. Data from Highlands County wells less than 90 feet deep (from Bishop, 1956)

$\left[\mathrm{CaCO}_{3}\right.$, calcium carbonate; $\mathrm{Fe}$, iron; $\mathrm{Ca}$, calcium; $\mathrm{Mg}$, magnesium; $\mathrm{Na}$, sodium; $\mathrm{K}$, potassium; $\mathrm{HCO}_{3}$, bicarbonate; $\mathrm{SO}_{4}$, sulfate; $\mathrm{Cl}$, chloride; F, fluoride; $\mathrm{NO}_{3}$, nitrate; $\mathrm{mg} / \mathrm{L}$, milligrams per liter; --, no data; nd, not detected. Geologic unit: $\mathrm{H}$, Hawthorn; P, Pleistocene; T, Tamiami]

\begin{tabular}{|c|c|c|c|c|c|c|c|c|c|c|c|c|c|c|}
\hline $\begin{array}{c}\text { Well } \\
\text { number }\end{array}$ & $\begin{array}{l}\text { Depth } \\
\text { (feet) }\end{array}$ & $\begin{array}{c}\text { Geo- } \\
\text { logic } \\
\text { unit }\end{array}$ & $\begin{array}{c}\mathrm{pH} \\
\text { (units) }\end{array}$ & $\begin{array}{l}\text { Color } \\
\text { (units) }\end{array}$ & $\begin{array}{c}\text { Total } \\
\text { hardness } \\
(\mathrm{mg} / \mathrm{L} \text { as } \\
\left.\mathrm{CaCO}_{3}\right)\end{array}$ & $\begin{array}{c}\mathrm{Fe} \\
(\mathrm{mg} / \mathrm{L})\end{array}$ & $\begin{array}{c}\mathrm{Ca} \\
(\mathrm{mg} / \mathrm{L})\end{array}$ & $\begin{array}{c}\mathrm{Mg} \\
(\mathrm{mg} / \mathrm{L})\end{array}$ & $\begin{array}{c}\mathrm{Na}+\mathrm{K} \\
(\mathrm{mg} / \mathrm{L})\end{array}$ & $\begin{array}{l}\mathrm{HCO}_{3}^{-} \\
(\mathrm{mg} / \mathrm{L})\end{array}$ & $\begin{array}{c}\mathrm{SO}_{4} \\
(\mathrm{mg} / \mathrm{L})\end{array}$ & $\begin{array}{c}\mathrm{Cl} \\
(\mathrm{mg} / \mathrm{L})\end{array}$ & $\begin{array}{c}F \\
(m g / L)\end{array}$ & $\begin{array}{c}\mathrm{NO}_{3} \\
(\mathrm{mg} / \mathrm{L})\end{array}$ \\
\hline 26 & 35 & $\mathrm{H}$ & 6.2 & 0 & 8 & 0.01 & 0.7 & 6.8 & -- & 6 & 2 & 11 & nd & 0.2 \\
\hline 128 & 90 & $\mathrm{H}$ & 6.4 & 2 & 2 & nd & -- & -- & 7.3 & 9 & 1 & 6 & nd & .6 \\
\hline 149 & 24 & $\mathrm{H}$ & 5.2 & 1 & 7 & .01 & 2.3 & .4 & 13 & 6 & 9 & 10 & nd & 8 \\
\hline 179 & 30 & $\mathrm{P}$ & 5.1 & 4 & 5 & .03 & 1.5 & .4 & 9.4 & 6 & 0.8 & 14 & 0.1 & .1 \\
\hline 214 & 86 & $\mathrm{H}$ & 6.1 & 3 & 2 & .06 & .8 & .1 & 8.2 & 9 & 1.5 & 6 & nd & 3.6 \\
\hline 235 & 25 & $\mathrm{H}$ & 4.7 & 30 & 14 & .5 & 2.4 & 2 & 4.9 & 2 & 39 & 57 & nd & .5 \\
\hline 273 & 65 & $\mathrm{~T}$ & 6.2 & 7 & 22 & 1.1 & 7.9 & .6 & 4 & 28 & 1 & 6 & .4 & .5 \\
\hline 330 & 49 & $\mathrm{H}$ & 5.9 & 7 & 9 & nd & 1.9 & 1 & 4.4 & 12 & .8 & 5 & .1 & .5 \\
\hline 334 & 88 & $\mathrm{~T}$ & 7.3 & 104 & 446 & 1.2 & 91 & 53 & 219 & 530 & 20 & 330 & .2 & .9 \\
\hline 337 & 45 & $\mathrm{P}$ & 7.3 & 60 & 255 & .72 & 89 & 7.8 & 12 & 310 & nd & 20 & .2 & .9 \\
\hline 351 & 35 & $\mathrm{P}$ & 5.4 & 5 & 13 & nd & 3.6 & 1 & 13 & 6 & 1 & 16 & nd & 18 \\
\hline 357 & 30 & $\mathrm{H}$ & 6.3 & 30 & 43 & 3.2 & 9.9 & 4.5 & 6.3 & 64 & 3 & 6 & .4 & .7 \\
\hline 376 & 20 & $\mathrm{H}$ & 5.7 & 7 & 14 & .62 & 3.5 & 1.3 & 7.7 & 20 & 1 & 9 & .2 & .2 \\
\hline 393 & 80 & $\mathrm{H}$ & 5.8 & 12 & 27 & 1.1 & 7.5 & 2 & 20 & 29 & 4.5 & 6 & .5 & -- \\
\hline 394 & 88 & $\mathrm{H}$ & 5.2 & 7 & 2 & nd & .4 & .2 & 4.3 & 3 & .2 & 4 & nd & 3.4 \\
\hline
\end{tabular}




\section{Sulfide}

Sulfide concentrations were analyzed for 20 of the samples. Values ranged from less than the detection limit of $1.0 \mathrm{mg} / \mathrm{L}$ to $4.6 \mathrm{mg} / \mathrm{L}$ for the surface-water sample (KRDRMONT) at Site D.

Well OKF-42, tapping the FAS, was not sampled for sulfide. Generally higher sulfide concentrations at Site D than at Site C could indicate that organic-rich surface water could be recharging the shallow ground water at that site.

\section{Strontium and Strontium Isotopes}

Concentrations of dissolved strontium were determined for all samples (table 1). A major source of strontium to ground water is dissolution of marine fossils in shell and limestone deposits (Hem, 1985). The maximum value was about 18,500 micrograms per liter $(\mu \mathrm{g} / \mathrm{L})$ for the sample from well OKF-42, which taps the FAS. For the samples from Site C, the range was from 66 to $1,100 \mu \mathrm{g} / \mathrm{L}$ with a median of about $800 \mu \mathrm{g} / \mathrm{L}$ and for Site $\mathrm{D}$, from 490 to $1,500 \mu \mathrm{g} / \mathrm{L}$ with a median of about 1,000 $\mu \mathrm{g} / \mathrm{L}$ (fig. 6).

Strontium concentrations reported by Sacks and Tihansky (1996) for 22 wells tapping the intermediate aquifer system (IAS) in southwestern Florida ranged from $100 \mu \mathrm{g} / \mathrm{L}$ to $30,100 \mu \mathrm{g} / \mathrm{L}$. Wells tapping the FAS in that area had strontium concentrations as high as 56,000 $\mu \mathrm{g} / \mathrm{L}$. In Okeechobee County,

30 samples from wells tapping the Upper Floridan aquifer (UFA) had strontium concentrations ranging from $460-33,200 \mu \mathrm{g} / \mathrm{L}$, with a median of $10,500 \mu \mathrm{g} / \mathrm{L}$ (Bradner, 1994). The low strontium concentrations from all samples from sites C and D indicate little influence from the FAS. 
SITE C

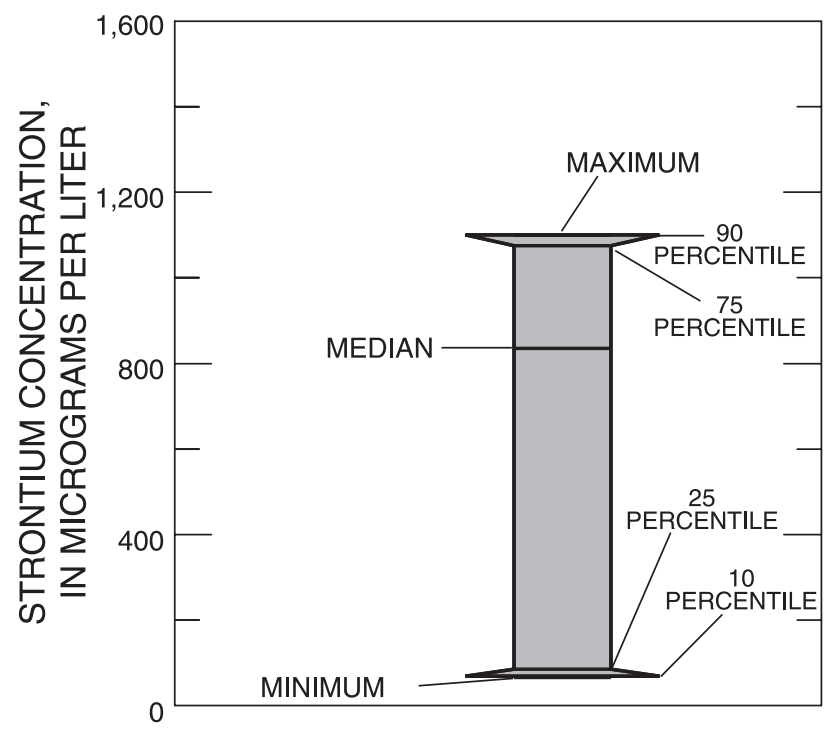

SITE D

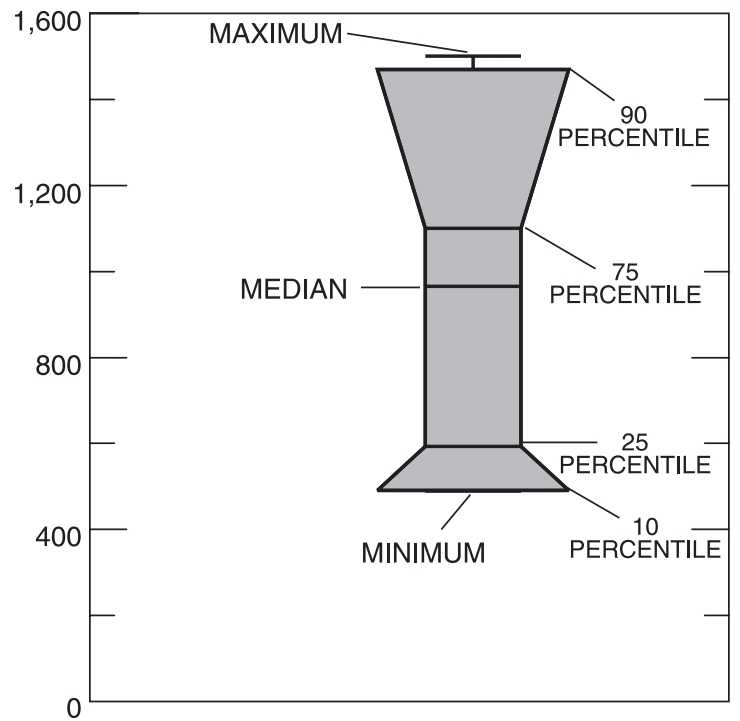

Figure 6. Strontium concentration data. 
The ratio of ${ }^{87} \mathrm{Sr} /{ }^{86} \mathrm{Sr}$ also was determined for all samples. The ratio has varied over geologic time and sediments generally maintain the ratio present in the seawater in which they were deposited (Veizer, 1989). Ground water, in turn, dissolves calcite (which contains strontium that has substituted for calcium in the crystal lattice) from the aquifer matrix and generally has the same ratio of ${ }^{87} \mathrm{Sr} /{ }^{86}$ as the aquifer material with which it reacts. The sample from well OKF-42, which taps the Eocene-age rocks of the FAS, had a ratio of 0.70773 (Eocene-age seawater; Veizer, 1989). Two samples from Site D, KRDRMONT (the surface-water sample) and KRDCKSS (the small seepage meter sample) also had an Eocene-age strontium isotope ratio (fig. 7). The fact that water from the seepage meter had about the same ratio as the surface-water sample could indicate inflow of surface water into the streambed. However, the fact that the piezometer and shallow wells at Site D had ratios typical of surficial or intermediate aquifer sediments indicates that the influence of surface water on ground water is limited to a relatively small area. The reason for an Eocene-age ratio in surface water is unclear but could result from runoff of FAS water used for irrigation in upstream areas mixing with rainfall runoff, which contains almost no strontium. Although the ${ }^{87} \mathrm{Sr} /{ }^{86} \mathrm{Sr}$ ratio for the surface-water samples have an Eocene-age signature (possibly implying influence from the FAS), the actual concentrations of strontium are very low.

At Site $\mathrm{C}$, the surface-water sample (KRCNC38) and the samples from the seepage meters (KRCNKSS and KRCNKSL) had similar strontium concentrations and ${ }^{87} \mathrm{Sr} /{ }^{86} \mathrm{Sr}$ ratios, possibly indicating that surface water is flowing into the streambed. Strontium concentrations at Site $\mathrm{C}$ were lower than at Site $\mathrm{D}$, but ${ }^{87} \mathrm{Sr} /{ }^{86} \mathrm{Sr}$ ratios were higher, indicating a Miocene age for the surface-water sample. The higher ${ }^{87} \mathrm{Sr} /{ }^{86} \mathrm{Sr}$ ratios at Site $\mathrm{C}$ indicate that the surface water is a mixture of precipitation and shallow ground water, with no discernible influence from FAS. 


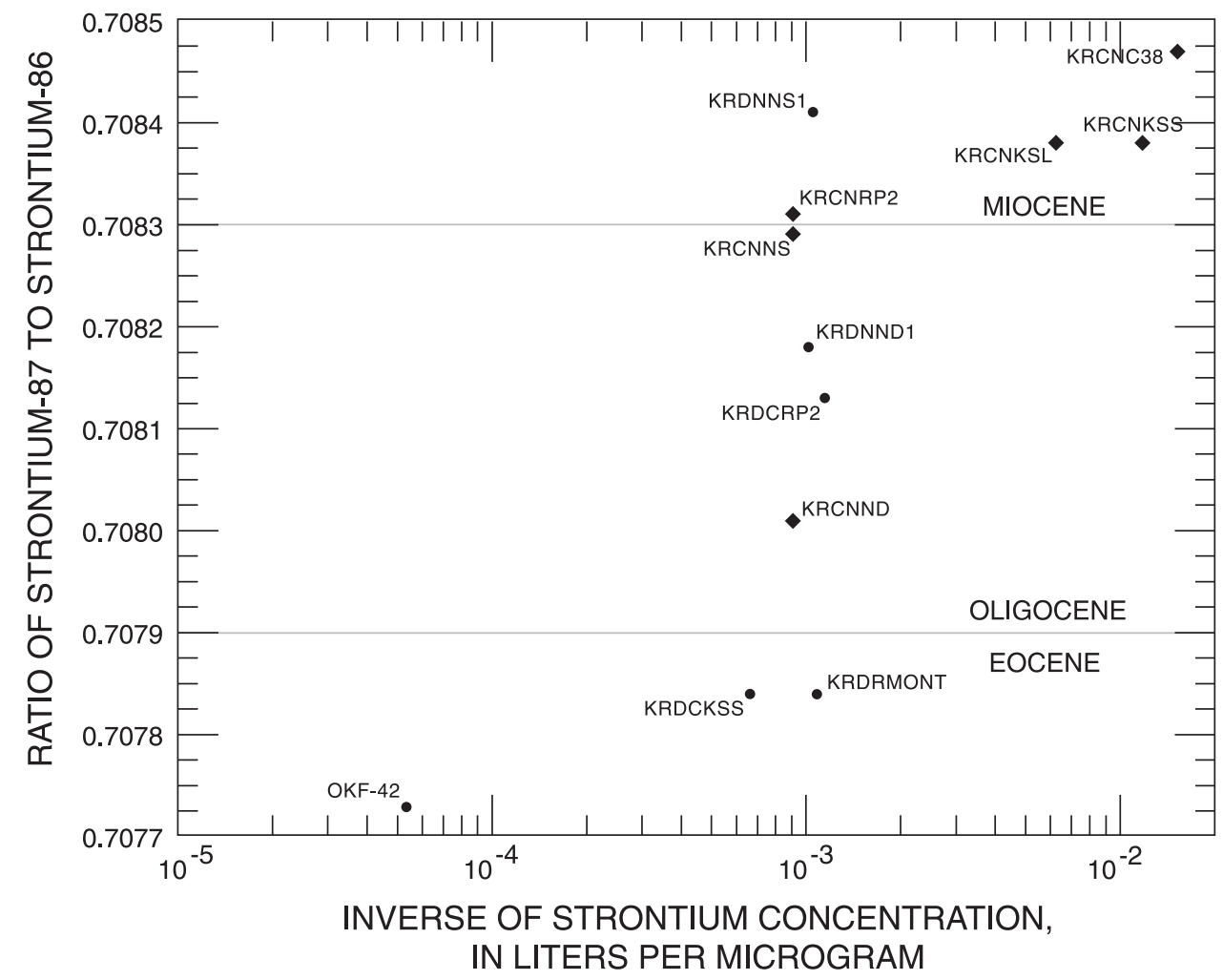

Figure 7. Relation between ratio of strontium- 87 to strontium-86 and strontium concentration. 


\section{Carbon Isotopes}

Values of $\delta^{13} \mathrm{C}$ and ${ }^{14} \mathrm{C}$ for dissolved inorganic carbon were determined for seven samples (the number of samples was limited by the high cost of the ${ }^{14} \mathrm{C}$ analysis). The sample from well OKF-42 had a $\delta^{13} \mathrm{C}$ value of -2.08 per mil and a ${ }^{14} \mathrm{C}$ value of 1.61 percent modern, typical for water from the confined FAS (Phelps, 2001). Values of $\delta^{13} \mathrm{C}$ for the other samples from Site D were much lighter (more negative), ranging from -8.9 to -12.36 per mil. Sacks and Tihansky (1996) found that $\delta^{13} \mathrm{C}$ values were lighter in the IAS than in the FAS, and Katz and others (1995) also found $\delta^{13} \mathrm{C}$ values to be progressively lighter from the FAS to the IAS/confining unit and then to the SAS. The ${ }^{14} \mathrm{C}$ value for the sample from a seepage meter at Site C (KRCNKSS) was slightly greater than 100 percent modern, indicating recently recharged water.

A comparison of the ${ }^{14} \mathrm{C}$ values for the deep SAS wells nearest to the river at each site (KRCNND and KRDNND1) and the mid-depth SAS wells farthest from the river (KRCFFM and KRDFFM) apparently indicates that the ground water in the SAS is younger (contains a higher portion of modern water) at Site D than at Site C. This seems to support the conclusion that disturbing the sediments at the dredged site might have resulted in increased upward leakage of water from the FAS to the SAS. The strontium isotope data, however, lead to the opposite conclusion: the water from the deep well near the river (KRDNND1) at Site D, the undisturbed area, seems to have a greater fraction of younger water than the deep well near the river at Site C (KRCNND), based on the ${ }^{87} \mathrm{Sr} /{ }^{86} \mathrm{Sr}$ ratio (fig. 7). 


\section{Oxygen-18 and Deuterium}

All samples were analyzed for $\delta^{18} \mathrm{O}$ and $\delta \mathrm{D}$. The distribution of $\delta^{18} \mathrm{O}$ and $\delta \mathrm{D}$, as well as other environmental isotopes, is shown in figures 8 and 9. Values of $\delta^{18} \mathrm{O}$ for Site $\mathrm{C}$ ranged from 0.09 per mil for seepage meter KRCNKSL to -2.1 per mil for the sample from the river channel (KRCNC38) (table 1). For Site D, the values ranged from -0.74 per mil for seepage meter KRDCKSS to -2.76 per mil for the surface-water sample (KRDRMONT). Values of $\delta \mathrm{D}$ for Site $\mathrm{C}$ ranged from 0.4 per mil for KRCNKSL to -10.7 per mil for the sample from KRCNC38. For Site D, the values ranged from -1.6 per mil for KRDCKSS to -14.2 per mil for KRDRMONT. A sample of rainfall collected in St. Lucie County by Crandall (2000) had a $\delta \mathrm{D}$ value of -18.0 and $\delta^{18} \mathrm{O}$ value of -3.9. The data define a local meteoric water line similar to the trend for water samples from west-central Florida reported by Swancar and Hutchinson (1992), rather than following the trend of the Global Meteoric Water Line described by Craig (1961) (fig. 10). For each site, the surface-water sample had the lightest $\delta^{18} \mathrm{O}$ and $\delta \mathrm{D}$ values, although for the ground-water samples, trends with depth are not apparent. The samples from both seepage meters at Site $\mathrm{C}$ and the small seepage meter at Site $\mathrm{D}$ seem to be enriched in $\delta^{18} \mathrm{O}$ and $\delta \mathrm{D}$, possibly because of the effects of evaporation. Also, seasonal effects can produce significant differences in the isotopic content of precipitation (Coplen, 1993), so the observed differences in some samples could result from recharge that took place during different seasons.

\section{Tritium and Tritium/Helium-3}

Seventeen water samples were analyzed for tritium and ${ }^{3} \mathrm{H} /{ }^{3} \mathrm{He}$ in order to estimate their age. Unfortunately, due to problems during sample collection, reliable ages could not be calculated for most of the samples. 


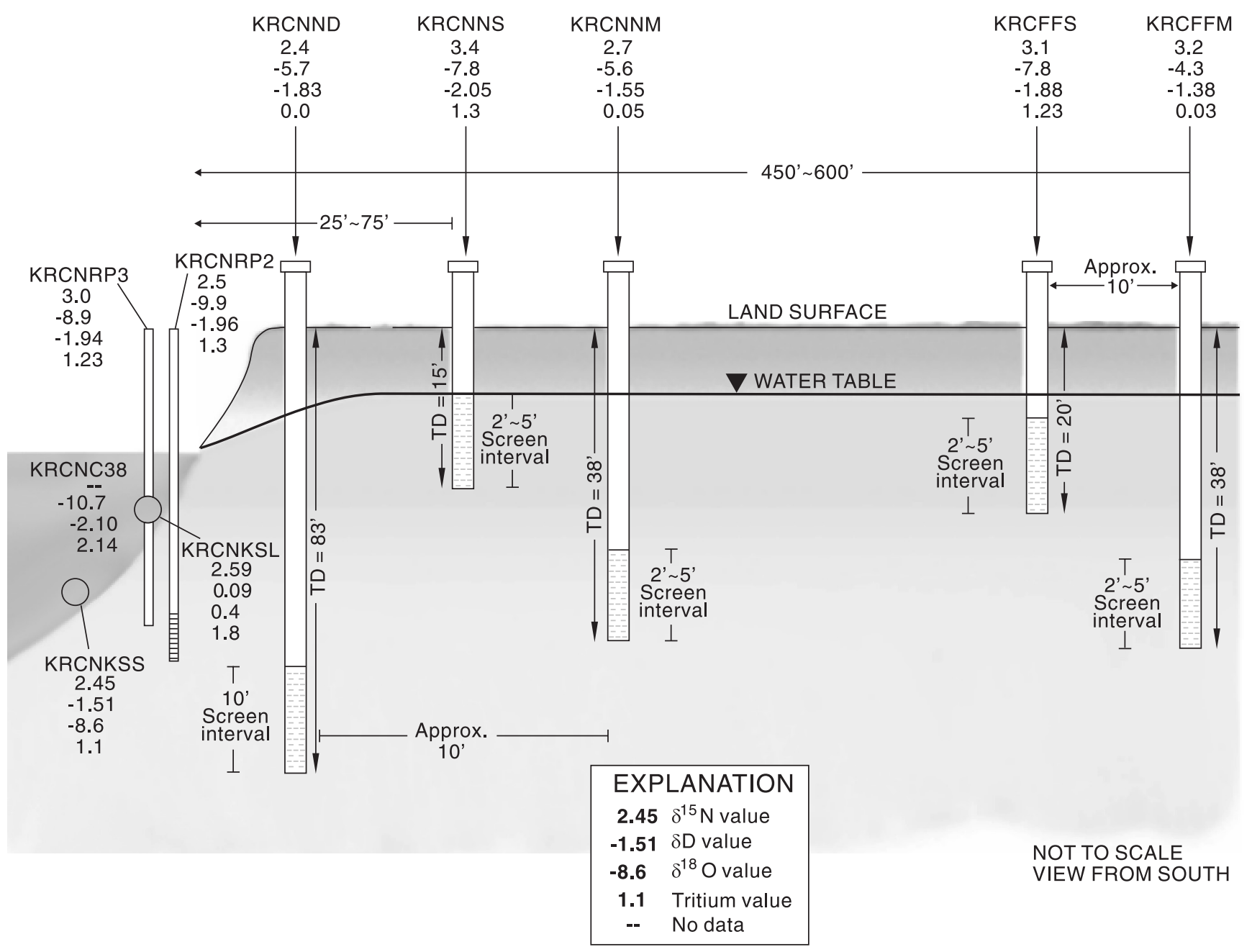

Figure 8. Distribution of tritium and oxygen, hydrogen, and nitrogen isotope data for Site C. 


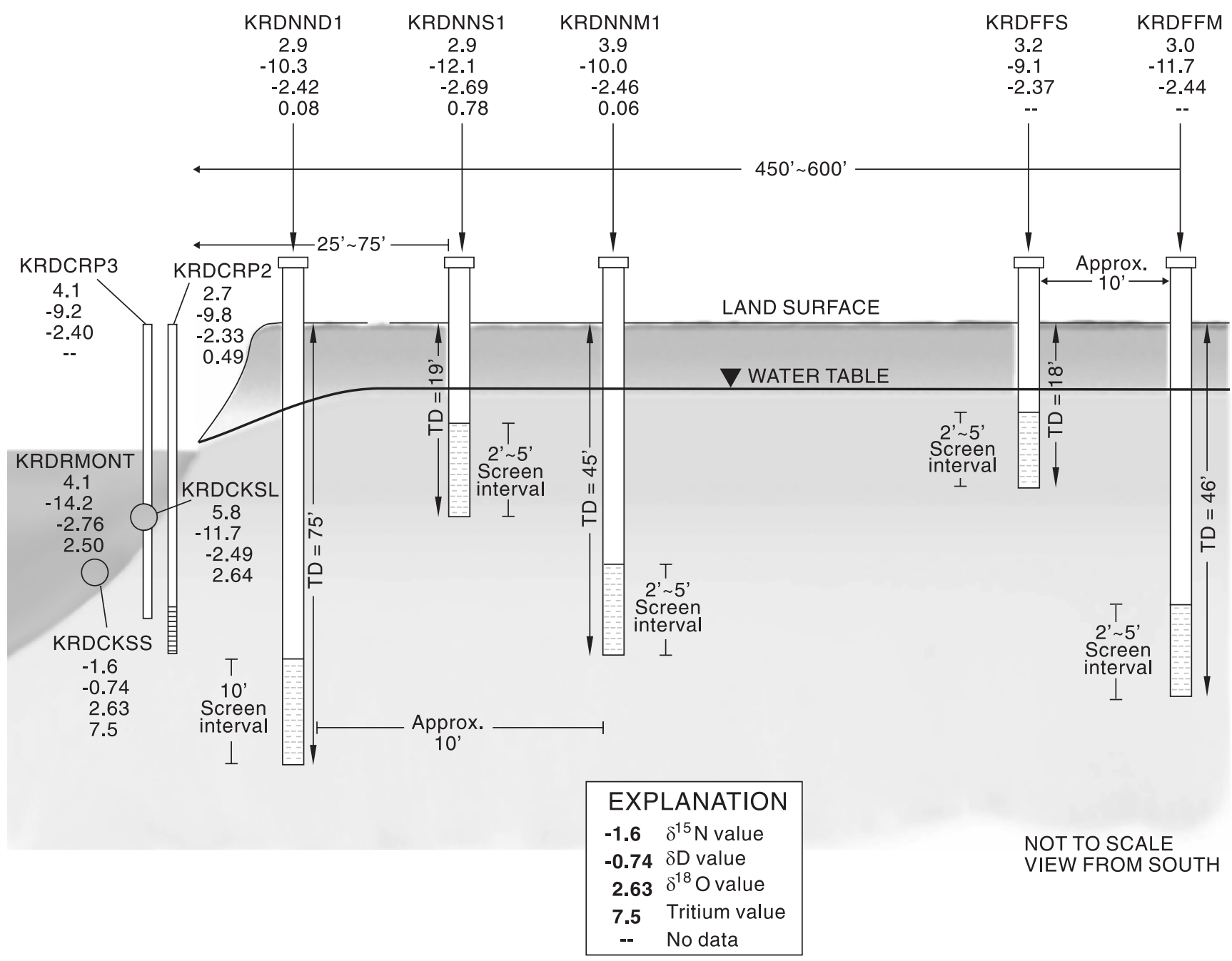

Figure 9. Distribution of tritium and oxygen, hydrogen, and nitrogen isotope data for Site D. 


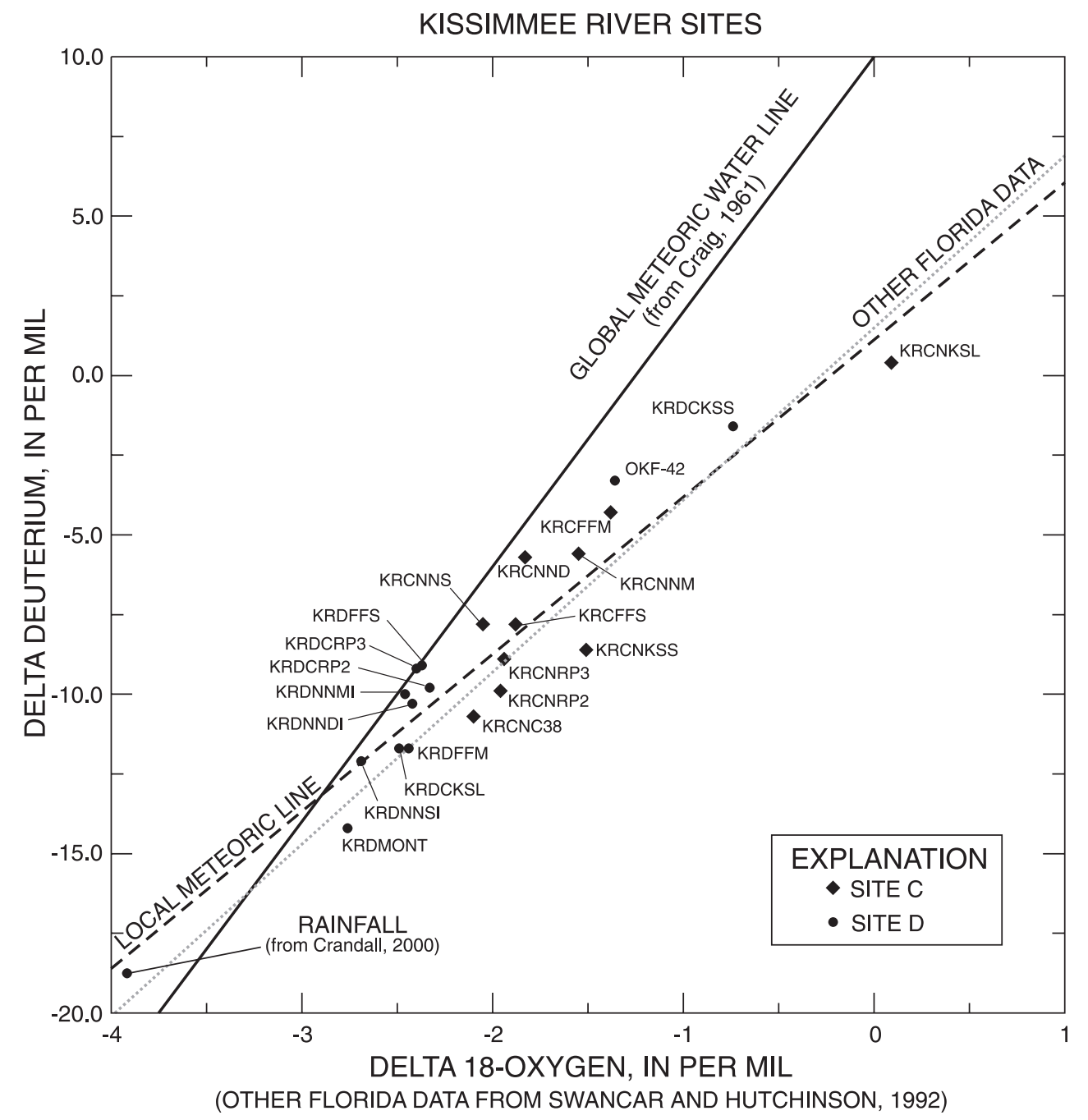

Figure 10. Relation between delta deuterium and delta oxygen-18. 
Tritium values ranged from 0 to 2.64 tritium units (table 1, figs. 8 and 9). Several of the samples (KRDNND1, KRDNNM1, KRCFFM, KRCNND, and KRCNNM) contained essentially no tritium and cannot be dated using the ${ }^{3} \mathrm{H} /{ }^{3} \mathrm{He}$ method, except in a general way. The absence of tritium indicates that all the water in those samples recharged the aquifer prior to the start of atmospheric nuclear testing during the late 1950 's and early 1960 's. The tritium values for the seepage meter samples KRCNKSS, KRCNKSL, KRDCKSS, and KRDCKSL were similar to values for the surface-water samples (KRCNC38 and KRDMONT), which represent "background" values for precipitation in Florida (Thatcher, 1962). This seems to indicate that surface water is locally recharging the adjacent sediments at both sites. Water samples from the piezometers at Site C (fig. 8) had tritium values essentially the same as the shallow wells at the site (depths 15-20 ft) and probably represent the decay of background levels of tritium in local precipitation. The water from the deeper wells, as expected, contained virtually no tritium. At Site D (fig. 9), the shallow well and the deeper piezometer both had low tritium values, perhaps indicating low rates of recharge at the site.

Data from the laboratory analysis for ${ }^{3} \mathrm{H} /{ }^{3} \mathrm{He}$ are given in the appendix. The laboratory analysis indicated that many of the samples probably had gas fractionation (partial loss of helium relative to neon). This was caused by dissolved gases in the water that caused a loss of helium-4. Such dissolved gases could include methane, carbon dioxide, or hydrogen sulfide (L.N. Plummer, USGS, oral commun., 2000). Samples with a delta-helium value less than the value of delta-neon had gas fractionation (L.N. Plummer, USGS, oral commun., 2000). Hydrogen sulfide was present in many of the samples. 
Some of the water samples probably contained air that was introduced either during or after sampling. For some samples, this may have occurred during sampling using a peristaltic pump. Although it was recognized that this sampling method was not ideal, there was no other way to obtain a sample from some piezometers and seepage meters. Other samples, however, were collected using a submersible pump and appeared to be undisturbed when collected. Possibly, the copper sampling tubes that were sealed in the field under very warm conditions may have contracted in the cooler temperatures of the laboratory, thus allowing air into the samples. Other sources of problems were gas stripping at the unsaturated zone as the sample was being collected, and gas fractionation. Gas stripping occurs when the total pressure of gases in ground water exceeds 1 atmosphere and the suction pressure of the pump is not high enough to keep the gases in solution; helium and other gases can bubble out of solution and adhere to the sidewalls of the sampling tube (Crandall, 2000). The small number of samples with reliable age estimates precludes any detailed interpretation of ages and interactions between surface water and ground water.

\section{Nitrogen Isotopes}

For all samples with sufficient nitrate concentrations, values of $\delta^{15} \mathrm{~N}$ were determined (table 1). For Site C, values ranged from 1.1 per mil to 3.4 per mil, with a median value of about 2.5 per mil (fig. 11). For Site D, the values ranged from 2.7 per mil to 7.5 per mil, with a median of about 3.0 per mil (fig. 11). Although the median values for the two sites are only slightly different, the values for Site D generally are higher, as indicated by the higher maximum value and higher values for the 75th and 90th percentiles. Variations in $\delta^{15} \mathrm{~N}$ values with depth (fig. 12) can be indicative of nitrification or denitrification processes. Values of $\delta^{15} \mathrm{~N}$ and nitrate concentrations can be used to calculate enrichment factors, which can be useful in comparing nitrification or denitrification rates in ground water (Crandall, 2000). Statistical testing for variations of nitrate concentration with depth and additional sampling to determine seasonal variations in $\delta^{15} \mathrm{~N}$ would be useful in understanding the cycling of nitrogen at the sites. 

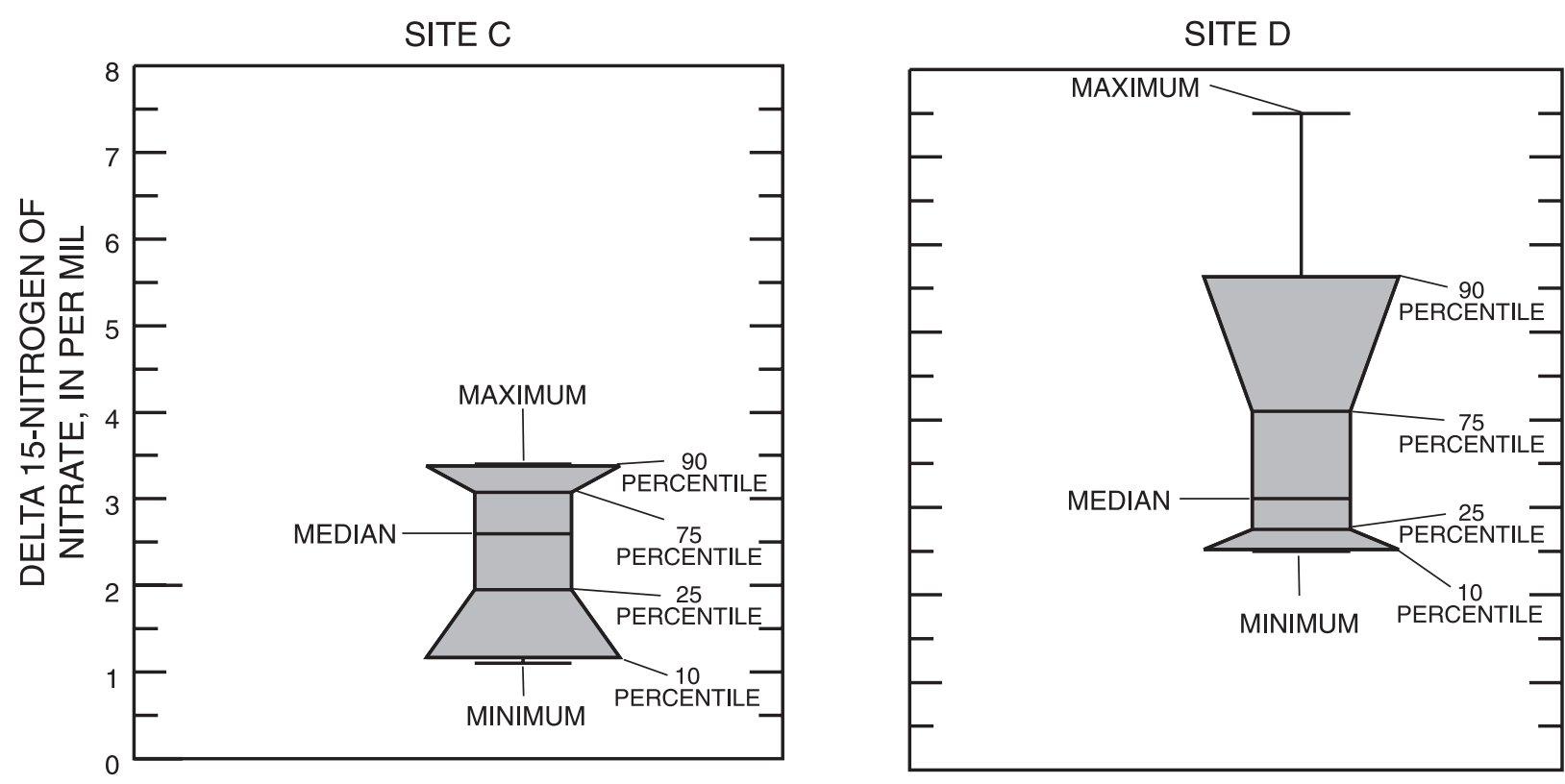

Figure 11. Delta nitrogen-15 data. 


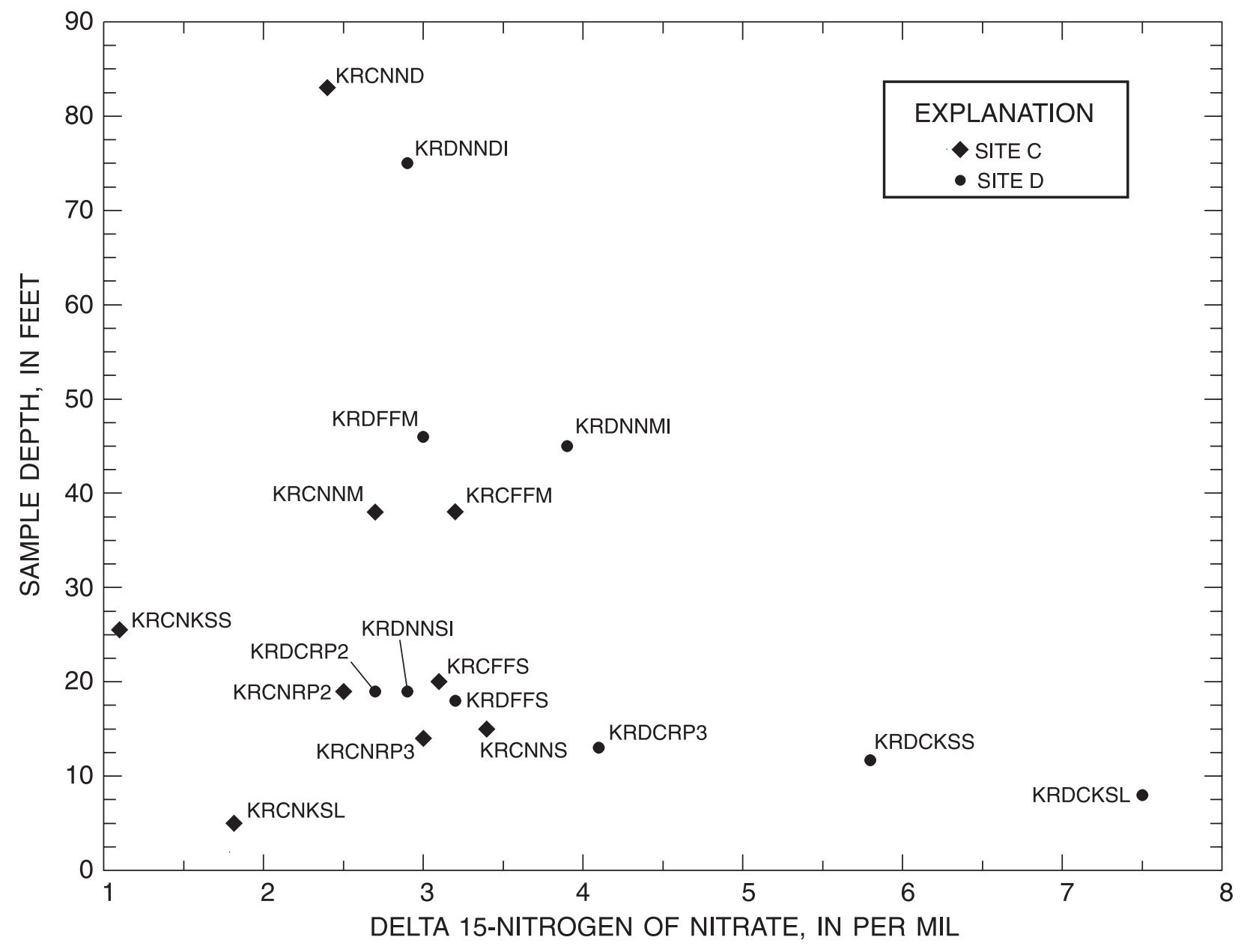

Figure 12. Relation between sampling depth and delta nitrogen-15 values. 
Values of nitrogen isotopes have been used to differentiate the source of the nitrate nitrogen in water samples. The following ranges for various sources of nitrogen were given by Coplen (1993): soil nitrogen has $\delta^{15} \mathrm{~N}$ values in the range of +2 to +9 per mil; commercial fertilizer, -2 to +7 per mil but typically less than +3.5 per mil; and animal wastes, +10 to +23 per mil, with fresh wastes in the range of +1 to +6 per mil. The deep and mid-depth wells had variations of $\delta^{15} \mathrm{~N}$ values between sites of only about 1 per mil, but values for the shallow ground water exhibited greater variability (table 1, figs 8. and 9). The values for Site D were generally higher than for Site C. For the samples from Site D, soil nitrogen can likely account for the $\delta^{15} \mathrm{~N}$ values observed, although animal wastes also could be a possible source. For Site C, soil nitrogen could account for the values greater than 2 per mil, while fertilizer could account for values less than 2 per mil. At Site D, the samples from the two seepage meters were the most enriched in $\delta^{15} \mathrm{~N}$, more so than the surface-water sample or samples from any of the wells. At Site $\mathrm{C}$ the samples from the seepage meters were less enriched than samples from the wells; the surface-water sample did not contain sufficient nitrate or ammonium for nitrogen isotope analysis. Mixing of waters affected by fertilizers and by animal wastes probably affects the observed $\delta^{15} \mathrm{~N}$ values at both sites. 


\section{SUMMARY AND COMPARISON OF CHEMICAL AND ISOTOPIC DATA FROM SITES C AND D}

Data from Sites C and D are summarized in table 3. The concentrations of most constituents (including fluoride, strontium and carbon isotopes, and tritium) are similar in the surface water and the deep seepage meter at both sites. This may indicate that surface water is locally recharging the ground water. An alternative explanation, however, is that some of the seepage meters leaked, allowing surface water, rather than ground water, to be sampled.Water from the mid-depth and deep SAS wells contained no tritium, implying that recharge occurred more than 50 years ago. Unfortunately, tritium-helium-3 dating for water from the seepage meters, piezometers, and shallow SAS wells was not successful, probably because of the presence of dissolved gases such as sulfide in the water, so estimated ages of shallow ground-water samples could not be determined. The Ecocene-age ${ }^{87} \mathrm{Sr} /{ }^{86} \mathrm{Sr}$ ratio for the surface water and seepage meter samples from Site D probably indicate that nearly all of the strontium in the water came from the dissolution of Eocene-age rocks, implying that some portion of the water came from

the FAS, perhaps from runoff of aquifer irrigation water. The Miocene-age ${ }^{87} \mathrm{Sr} /{ }^{86} \mathrm{Sr}$ ratio at Site C could result from mixing of some FAS water with a significant amount of water from younger (post-Mioceneage) sediments, resulting in an apparently younger age ratio.

Some of the isotopic data seem to be contradictory: ${ }^{14} \mathrm{C}$ data apparently indicate that ground water in the SAS is younger at Site D than at Site C, whereas ${ }^{87} \mathrm{Sr} /{ }^{86} \mathrm{Sr}$ ratios lead to the opposite conclusion. More detailed analysis of major ions and nutrients for all sampling points, along with flow measurements and the limited amount of isotopic data, could allow more definitive interpretation of isotope data and provide additional insight into mixing of ground water and surface water at the sites. 
Table 3. Comparison of data from the two sites

\begin{tabular}{|c|c|c|}
\hline Constituent & Site C (dredged channel) & Site D (remnant river oxbow) \\
\hline Fluoride & $\begin{array}{l}\text { Median value } 0.48 \mathrm{mg} / \mathrm{L} \text {. Below detection limit in } \\
\text { surface water and deep seepage meter }\end{array}$ & $\begin{array}{l}\text { Median value } 0.2 \mathrm{mg} / \mathrm{L} \text {. Below detection limit in sur- } \\
\text { face water and both seepage meters }\end{array}$ \\
\hline Strontium & $\begin{array}{l}\text { Range } 66-1,100 \mathrm{mg} / \mathrm{L} \\
\text { median } 800 \mathrm{mg} / \mathrm{L}\end{array}$ & $\begin{array}{l}\text { Range } 490-1,500 \mathrm{mg} / \mathrm{L} \\
\text { median } 1,000 \mathrm{mg} / \mathrm{L}\end{array}$ \\
\hline $\begin{array}{l}\text { Strontium- } 87 \text { to } \\
\text { strontium- } 86 \text { ratio }\end{array}$ & $\begin{array}{l}\text { Surface-water and both seepage meter samples had } \\
\text { Miocene-age ratios (younger water) }\end{array}$ & $\begin{array}{l}\text { Surface water and sample from one seepage meter } \\
\text { had Eocene-age ratios (older water) }\end{array}$ \\
\hline Carbon isotopes & $\begin{array}{l}\text { Deep seepage meter had recent recharge water and far } \\
\text { mid-depth well had old water ( } 18 \text { percent modern } \\
\text { carbon). Deep well near river had water with } 7 \text { per- } \\
\text { cent modern carbon (older water) }\end{array}$ & $\begin{array}{l}\text { Carbon-14 values ranging from } 23 \text { to } 47 \text { percent } \\
\text { modern. Data for deep well near river agrees with } \\
\text { tritium data (younger water) }\end{array}$ \\
\hline $\begin{array}{l}\text { Oxygen and hydro- } \\
\text { gen isotopes }\end{array}$ & $\begin{array}{l}\text { Data more distributed along meteoric line than data } \\
\text { from Site D }\end{array}$ & $\begin{array}{l}\text { Data all similar except deep seepage meter and } \\
\text { Floridan aquifer well, which had more similar values }\end{array}$ \\
\hline Tritium & $\begin{array}{l}\text { Well samples all had no tritium, implying old water. } \\
\text { Seepage meters and surface water had measurable tri- } \\
\text { tium }\end{array}$ & $\begin{array}{l}\text { Wells had no tritium, implying old ground water. } \\
\text { Seepage meter and surface water had measurable tri- } \\
\text { tium }\end{array}$ \\
\hline Nitrogen isotopes & $\begin{array}{l}\text { Fertilizer and soil nitrogen can account for observed } \\
\text { values. Mixing of sources probably occurs }\end{array}$ & $\begin{array}{l}\text { Soil nitrogen accounts for nearly all values. Animal } \\
\text { wastes can account for higher values. Mixing of } \\
\text { sources probably occurs }\end{array}$ \\
\hline
\end{tabular}




\section{SELECTED REFERENCES}

Adamski, J.C., 1998, Potentiometric surface of the Upper Floridan aquifer in the St. Johns River Water Management District, Florida, and vicinity, May 1998: U.S. Geological Survey Open-File Report 98-648, 1 sheet.

Aravena, R., Evans, M.L., and Cherry, J.A., 1993, Stable isotopes of oxygen and nitrogen in source identification of nitrate from septic systems: Ground Water, v. 31, no. 2, p. 180-186.

Belanger, T.V., Heck, H.H., and Kennedy, C., 1994, Dissolved oxygen field studies in the Kissimmee River system: Final report to the South Florida Water Management District, 196 p.

Belanger, T.V., Heck, H.H., Kirkner, R., Jones, B., Krupa, S., Herr, J., and Butler, D., 1999, Kissimmee River groundwater seepage study: Final report submitted to the South Florida Water Management District, 66 p.

Bishop, E.W., 1956, Geology and ground-water resources of Highlands County, Florida: Florida Geological Survey Report of Investigations 15, 115 p.

Bohlke, J.K., and Denver, J.M., 1995, Combined use of groundwater dating, chemical, and isotopic analyses to resolve the history and fate of nitrate contamination in two agricultural watersheds, Atlantic coastal plain, Maryland: Water Resources Research, v. 31, no. 9, p. 2,319-2,339.

Bradner, L.A., 1994, Ground-water resources of Okeechobee County, Florida: U.S. Geological Survey Water-Resources Investigations Report 92-4166, 41 p.

-1999, Potentiometric surface of the Upper Floridan aquifer in the St. Johns River Water Management District, Florida, and vicinity, September 1998: U.S. Geological Survey Open-File Report 99-100, 1 sheet.

Burke, W.H., Denison, R.E., Hetherington, E.A., Koepnick, R.B., Nelson, H.F., and Otto, J.B., 1982, Variation of seawater ${ }^{87} \mathrm{Sr} /{ }^{86} \mathrm{Sr}$ throughout Phanerozoic time: Geology, v. 10, p. 516-519.

Coplen, T.B., 1988, Normalization of oxygen and hydrogen isotope data: Chemical Geology (Isotope Geoscience Section), v. 72, p. 293-297. 
1993, Uses of Environmental Isotopes in Alley, W.M., ed., Regional ground-water quality: New

York, Van Nostrand Reinhold, 634 p.

1994, Reporting of stable hydrogen, carbon, and oxygen isotopic abundances: Pure and Applied Chemistry, v. 66, p. 273-276.

Craig, Harmon, 1961, Isotopic variations in meteoric water: Science, v. 133, p. 1,702-1,703.

Crandall, C.A., 2000, Distribution, movement, and fate of nitrate in the surficial aquifer system beneath citrus groves, Indian River, Martin, and St. Lucie Counties, Florida: U.S. Geological Survey Water-Resources Investigations Report 00-4057, 69 p.

Fontes, J-C., and Garnier, J-M., 1979, Determination of the initial ${ }^{14} \mathrm{C}$ activity of the total dissolved carbon: A review of the existing models and new approach: Water Resources Research, v. 15, no. 2, p. 399-413.

Fontes, J-C., and Andrews, J.N., 1994, Accelerator mass spectrometry in hydrology: Nuclear Instruments and Methods in Physics Research, v. B 92, p. 367-375.

Fritz, P., and Fontes, J-C., eds., 1986, Handbook of environmental isotope geochemistry, v. 2, The terrestrial environment, B: Amsterdam, Elsevier Scientific Publishers.

Gonfiantini, R., 1981, The d-notation and the mass-spectrometric measurement techniques, in J.R. Gat and R. Gonfiantini, eds., Stable isotope hydrology: Deuterium and oxygen-18 in the water cycle, chap. 4, p. 35-84, International Atomic Energy Agency, Vienna, Austria.

Heaton, T.H.E., 1986, Isotopic studies of nitrogen pollution in the hydrosphere and atmosphere: A review: Chemical Geology, v. 59, p. 87-102.

Hem, J.D., 1985, Study and interpretation of the chemical characteristics of natural water (3d ed.): U.S. Geological Survey Water-Supply Paper 2254, 263 p.

Hess, J., Bender, M.L., and Schilling, J.G., 1986, Seawater ${ }^{87} \mathrm{Sr} /{ }^{86} \mathrm{Sr}$ evolution from Cretaceous to present: Science, v. 231, p. 979-984. 
Hodell, D.A., Mueller, P.A., and Garrido, J.R., 1991, Variations in the strontium isotopic composition of seawater during the Neogene: Geology, v. 19., p. 24-27.

Katz, B.G., Plummer, L.N., Busenberg, E., Revesz, K.M., Jones, B.F., and Lee, T.M., 1995, Chemical evolution of groundwater near a sinkhole lake, northern Florida. 2. Chemical patterns, mass transfer modeling, and rates of mass transfer reactions: Water Resources Research, v. 31, no. 6, p. 1,5651,584 .

Kohout, F.A., 1959, Hydrologic features of the Lake Istokpoga area, Highlands County, Florida: Florida Geological Survey Report of Investigations 19, pt. I, p. 9-33.

Komor, S.C., and Anderson, H.W., Jr., Nitrogen isotopes as indicators of nitrate sources in Minnesota sand-plain aquifers: Ground Water, v. 31, no. 2, p. 260-270.

Mook, W.G., 1980, Carbon-14 in hydrogeological studies in Fritz, P. and Fontes, J-C.,eds., 1980, Handbook of environmental isotope geochemistry, v. 1 The terrestrial environment, A: Amsterdam, Elsevier Scientific Publishers.

Pearson, F.J., Jr., and White, D.E., 1967, Carbon 14 ages and flow rates of water in the Carrizo Sand, Atascosa County, Texas: Water Resources Research, v. 3, no. 1, p. 251-261.

Phelps, G.G., 2001, Geochemistry and origins of mineralized waters in the Floridan aquifer system, northeastern Florida: U.S. Geological Survey Water-Resources Investigations Report 01-4112, $64 \mathrm{p}$.

Plummer, L.N., Rupert, M.G., Busenberg, E., and Schlosser, P., 2000, Age of irrigation water in ground water from the eastern Snake River plain aquifer, south-central Idaho: Ground Water, v. 38, no. 2, p. 264-283.

Sacks, L.A., and Tihansky, A.B., 1996, Geochemical and isotopic composition of ground water, with emphasis on sources of sulfate, in the Upper Floridan aquifer and intermediate aquifer system in southwest Florida: U.S. Geological Survey Water-Resources Investigations Report 96-4146, 67 p. 
Schlosser, P., 1992, Tritium $/{ }^{3} \mathrm{He}$ dating of waters in natural systems in Isotopes of noble gases as tracers in environmental studies, IAEA, Vienna, p. 123-145.

Swancar, A., and Hutchinson, C.B., 1992, Chemical and isotopic composition and potential for contamination of water in the Upper Floridan aquifer, west-central Florida, 1986-89: U.S. Geological Survey Water-Resources Investigations Report 92-47, 47 p.

Thatcher, L.L., 1962, The distribution of tritium fallout in precipitation over North America: International Association of Scientific Hydrology, VII, v. 2, p.48-58.

Tibbals, C.H., 1990, Hydrology of the Floridan aquifer system in east-central Florida: U.S. Geological Survey Professional Paper 1403-E, 98 p.

Viezer, J., 1989, Strontium isotopes in seawater through time: Annual Reviews of Earth and Planetary Science, v. 17, p. 141-167.

Wigley, T.M.L., 1975, Carbon 14 dating of groundwater from closed and open systems: Water Resources Research, v. 11, no. 2, p. 324-328.

Wood, W.W., 1976, Guidelines for collection and field analysis of ground-water samples for selected unstable constituents: U.S. Geological Survey Techniques of Water-Resources Investigations, book 1, chap. D2, 24 . 


\title{
APPENDIX
}

\author{
NOBLE GAS LABORATORY \\ LAMONT-DOHERTY EARTH OBSERVATORY \\ OF COLUMBIA UNIVERSITY, NEW YORK
}

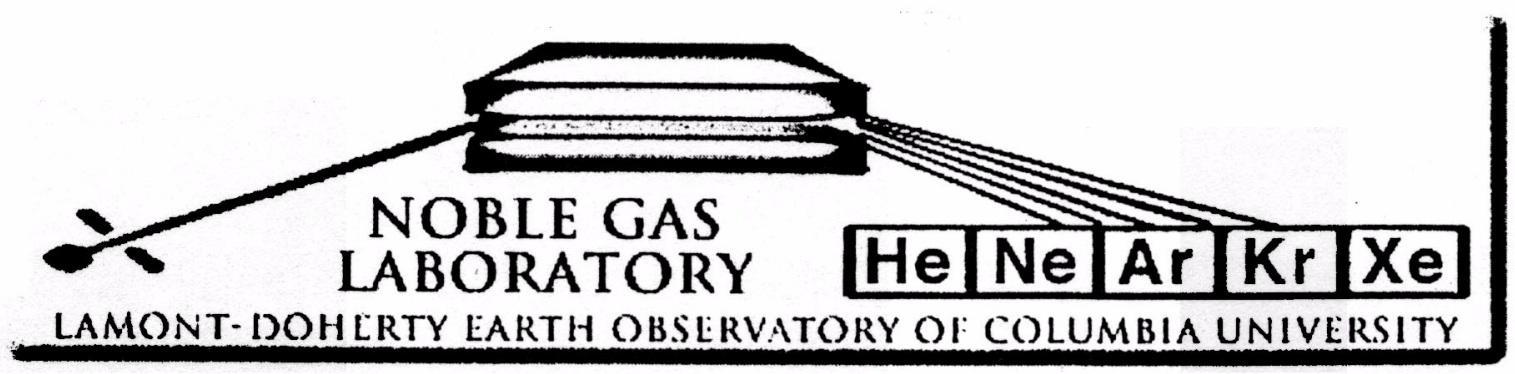

DATA RELEASE NO. 99-1.75.2 (Data Report; 12/12/2000)

\section{TRITIUM/HE MEASUREMENTS FOR THE USGS PROJECT 'FL-Phelps' (SAMPLES SUBMITTED BY Phelps')}

Peter Schiosser, Brent D. Turrin, C. McNally and Millie Kias

Larnont-Doherty Earth Observatory

Palisades, N.Y. 10964 


\section{TRITIUM/HE MEASUREMENTS FOR THE USGS PROJECT 'FL-Phelps (SAMPLE SUBMITTED BY Phelps)}

\section{DATA SUMMARY:}

No. of He/Ne samples submitted:

17 in duplicate

No. of $\mathrm{He} / \mathrm{Ne}$ measurements/extractions

19

performed

No. of $\mathrm{He} / \mathrm{Ne}$ data reported

15

No. of $\mathrm{He} / \mathrm{Ne}$ samples remeasured:

Problems

USGS:

LDEO:

Checks:

USGS charge (No. of samples meas./extract

19-0-2

-No. of Checks -No. of LDEO prob.)

one He sample run at no charge

No. of T samples submitted:

17 in duplicate

No. of T measurements performed

No. of T data reported

No. of T samples remeasured:

Problems

USGS:

LDEO:

Checks:

USGS charge (No. of samples meas. -No.

of Checks -No. of LDEO prob.)

17

Total No. of He/Ne samples charged:

Total No. of T samples charged: 


\section{USGS-FL-Phelps}

\begin{tabular}{|c|c|c|c|c|c|c|}
\hline Item & $\begin{array}{c}\text { USGS Lab } \\
\text { ID \# }\end{array}$ & Field ID \# & Tritium (TU) & $\delta^{3} \mathrm{He}$ & $\begin{array}{c}{ }^{4}{\mathrm{He} 10^{-8}}^{\mathrm{cm}^{3} \mathrm{STPg}^{-1}}\end{array}$ & $\begin{array}{c}\mathrm{Ne} 10^{-8} \\
\text { cm }^{3} \text { STPg }^{-1}\end{array}$ \\
\hline 1 & 993370001 & 993370001 & $\begin{array}{l}3.114 \\
2.593\end{array}$ & -1.710 & 3.939 & 15.612 \\
\hline 2 & 993370002 & 993370002 & $\begin{array}{l}6.205 \\
1.306\end{array}$ & -11.570 & 5.858 & 20.219 \\
\hline 3 & 993370003 & 993370003 & $\begin{array}{l}-0.029 \\
0.054\end{array}$ & -46.680 & 11.879 & 31.003 \\
\hline 4 & 993370004 & 993370004 & $\begin{array}{l}-0.002 \\
-0.021 \\
0.061\end{array}$ & $\begin{array}{l}-- \\
\text { pumped at branch; } \\
\text { USGS problem }\end{array}$ & -- & -- \\
\hline 5 & 993370005 & 993370005 & $\begin{array}{l}0.034 \\
-0.067\end{array}$ & -28.900 & 6.849 & 28.047 \\
\hline 6 & 993370006 & 993370006 & $\begin{array}{l}4.762 \\
1.232\end{array}$ & -18.270 & 6.266 & 21.011 \\
\hline 7 & 993370007 & 993370007 & $\begin{array}{l}1.298 \\
1.233\end{array}$ & -13.500 & 3.930 & 21.754 \\
\hline 8 & 993370008 & 993370008 & $\begin{array}{l}2.328 \\
2.139\end{array}$ & -1.250 & 7.926 & 35.944 \\
\hline 9 & 993370009 & 993370009 & $\begin{array}{l}1.499 \\
1.295\end{array}$ & -13.010 & 5.799 & 26.296 \\
\hline 10 & 993370010 & 993370010 & $\begin{array}{l}2.591 \\
2.445\end{array}$ & $\begin{array}{l}-2.260 \\
\text { High air contamina- } \\
\text { tion, USGS problem }\end{array}$ & $\begin{array}{l}4.568 \\
--\end{array}$ & $\begin{array}{l}22.097 \\
69.805\end{array}$ \\
\hline 11 & 993370011 & 993370011 & $\begin{array}{l}0.064 \\
-0.006\end{array}$ & -87.940 & 28.626 & 274.929 \\
\hline 12 & 993370012 & 993370012 & $\begin{array}{l}0.025 \\
2.631\end{array}$ & $\begin{array}{l}-- \\
-- \\
\text { pumped at branch; } \\
\text { USGS problem }\end{array}$ & $\begin{array}{l}-- \\
--\end{array}$ & $\begin{array}{l}-- \\
--\end{array}$ \\
\hline 13 & 993370013 & 993370013 & $\begin{array}{l}0.087 \\
0.084\end{array}$ & -13.560 & 15.900 & 66.467 \\
\hline 14 & 993370014 & 993370014 & $\begin{array}{l}1.228 \\
0.779\end{array}$ & -8.150 & 8.204 & 54.163 \\
\hline 15 & 993370015 & 993370015 & $\begin{array}{l}2.618 \\
2.495\end{array}$ & -0.430 & 13.919 & 60.087 \\
\hline 16 & 993370016 & 993370016 & $\begin{array}{l}2.543 \\
2.639\end{array}$ & -1.710 & 4.222 & 17.070 \\
\hline 17 & 993370017 & 993370017 & $\begin{array}{l}0.005 \\
0.486\end{array}$ & -12.110 & 19.397 & 72.444 \\
\hline
\end{tabular}

